\title{
EL ESTILO CIRCUMPUNEÑO EN EL ARTE DE LA PARAFERNALIA ALUCINÓGENA PREHISPÁNICA (ATACAMA Y NOROESTE ARGENTINO) ${ }^{1}$
}

\author{
Helena Horta Tricallotis ${ }^{234}$
}

Resumen

Este trabajo se basa en el análisis estilístico y contextual de diferentes elementos de la parafernalia alucinatoria proveniente de contextos funerarios del área circumpuneña, considerando una amplia muestra arqueológica y bibliográfica. Basado en ello, se define al estilo Circumpuneño, el cual habría tenido carácter macro regional debido a su extenso campo de dispersión (en Chile: costa de Atacama, cuenca del río Loa y salar de Atacama; en el noroeste de Argentina: quebrada de Humahuaca y la Puna de Jujuy). Se trata de un estilo distinto al de Tiawanaku, tanto en términos formales como temporales; en este trabajo se definen los rasgos que permiten considerarlo como un estilo aparte, poseedor de una profunda raigambre circumpuneña propia, aunque inspirada en conceptos altiplánicos, tales como la decapitación de individuos sacrificados en el marco de un rito con características chamánicas.

Palabras claves: complejo alucinógeno - área circumpuneña - desierto de Atacama - iconografía prehispánica - rito chamánico - sacrificio humano.

\section{Abstract}

This work is based on a stylistic and contextual analysis of hallucinogenic paraphernalia from funerary contexts in the circumPuna area. By considering a broad ranging archaeological sample and a thorough literature review, a circum-Puna style is defined that has a macro-regional character due to its wide field of dispersion (in Chile: Atacama coast, Loa River basin, and Salar de Atacama; in northwestern Argentina: Quebrada de Humahuaca and the Puna of Jujuy). This style is distinct from that of Tiawanaku both in its formal elements as well as its temporal placement. Here I define those features which classify this circum-Puna pattern as a separate style. These characteristics are those that possess a deep rooted relationship with the circum-Puna, although there is evidence of altiplano-inspired concepts such as the decapitation of individuals who appear to be sacrificed in the framework of a shamanic ritual.

Key words: Snuffing Complex - Circum-Puna area - Atacama Desert Prehispanic Iconography - Shamanic ritual - human sacrifice.

\section{* Introducción}

Ya desde los inicios de los estudios centrados en las hermosas tallas en madera de tabletas y tubos inhalatorios provenientes de distintos puntos de la zona atacameña (Región de Antofagasta, norte de Chile), surgió como inquietud el tema de la definición de estilos al interior del conjunto de dichos objetos. Desde entonces, el esfuerzo desarrollado por diferentes investigadores se había centrado en analizar, describir y definir el estilo que resultaba más llamativo o evidente entre las tabletas del complejo alucinógeno: el estilo Tiawanaku (Uhle 1913, 1915; Looser 1926; Oyarzún 1931; Núñez 1963; Mostny 1968-69; Wassén 1965, 1972; Torres 1983, 1984, 1986, 1987a y b, 1998, 2001a y b; Barón 1984; Thomas y Benavente 1984; Llagostera et al. 1988; Torres y Conklin 1995; Llagostera 1995, 2001, 2006a). Sin embargo, varios de los investigadores citados vislumbraron en su momento que no todas las tabletas presentaban rasgos tiawanaku, y que por lo tanto, existía un gran número de tabletas que diferían de dicho estilo. Junto con advertir la existencia de estilos que escapaban a las configuraciones altiplánicas, algunos investigadores clasificaron a aquellas con diferente iconografía, formato y técnica en un grupo aparte, denominándolas "tabletas no Tiawanaku" (Uhle 1913; Torres 1984, 1986; Llagostera 1995), pero ello no había avanzado mucho más allá del acto de declararlas diferentes, sin profundizar en su naturaleza especial. Mientras tanto, con el avance de las investigaciones en el tema ha ido quedando claro que el número de tabletas, tubos o espátulas con características técnicas e iconográficas claramente asimilables al arte Tiawanaku es reducido respecto del conjunto

Recibido: febrero 2012. Aceptado: junio 2012.

1 Este estudio fue presentado inicialmente como una ponencia en marzo del año 2007 en el Simposio The Southern Andean Iconographic Series. A Colloquium on Pre-Colombian Art and Archaeology, patrocinado por Dumbarton Oaks Pre-Colombian Program, Cotsen Institute of Archaeology, 
total, no sobrepasando el 17\% de los implementos alucinógenos registrados en el Museo R. P. Gustavo Le Paige de San Pedro de Atacama (en adelante MSPA) (Torres 1984, 1986; Llagostera 2006a).

En su momento, el investigador argentino P. Krapovickas, mientras estudiaba material trasandino estableció lo siguiente: "Todos los instrumentos para rapé que aparecen en la Puna (argentina) y en las zonas vecinas están ligados por una unidad estilística bien clara y definida, en la cual no entran las tabletas con motivos de Tiahuanaco ni las amazónicas" (Krapovickas 1958-59: 75). Torres, por su parte, en el marco de una investigación centrada en los modos de ingestión de plantas sicoactivas hizo un notable aporte al establecer por primera vez algunas diferencias temáticas y el uso de íconos especiales que presentaban tabletas no adscribibles a los cánones tiawanaku (Torres 1998).

Es precisamente la unidad estilística planteada por Krapovickas, la que intentaré definir en esta ocasión, tanto en términos formales como iconográficos, y para ello incluiré en el análisis diversos elementos de la parafernalia alucinógena provenientes de la región de San Pedro de Atacama, la costa de Antofagasta y el área loína, que eran desconocidos en su época. Al mismo tiempo, siguiendo los planteamientos de Torres -los cuales me han resul-

Universidad de Chile (Departamento de Antropología) y State University of New York, Binghamton. Una versión ampliada del presente artículo con el título "Sacrificadores y Víctimas. Hacia la definición del estilo Circumpuneño en el complejo alucinógeno de la zona atacameña y noroeste argentina" aparecerá publicada en The Southern Andean Iconographic Tradition. W. Isbell y M. Uribe (Edits.), Coedición de Dumbarton Oaks Pre-Colombian Program, Cotsen Institute of Archaeology, State University of New York, Binghamton y Universidad de Chile. Dumbarton Oaks, Washington, Estados Unidos.

2 Académica del Instituto de Investigaciones Arqueológicas y Museo R. P. Gustavo Le Paige (IIAM), Universidad Católica del Norte, San Pedro de Atacama. CHILE. Email: horta.helena@gmail. com.

3 Participante en el Proyecto de Investigación Asociativa de Conicyt Anillo ACT-96 titulado "Interacciones y movilidad humanas en poblaciones prehispánicas del norte y centro de Chile: un enfoque integrador para las Ciencias Sociales utilizando marcadores biomédicos, genéticos, químicos y mineralógicos", dirigido por Germán Manríquez (Universidad de Chile).

4 Centro de Investigaciones del Hombre en el Desierto (CIHDE), Arica, Chile. tado especialmente iluminadores- pretendo definir la temática de este estilo de tabletas y fijar con claridad sus diferencias respecto de Tiawanaku.

Núñez aplicó en 1963 la clasificación previamente propuesta por Krapovickas al material proveniente de San Pedro de Atacama y el vecino río Loa, y reconoció en su Tipo II claras influencias Tiawanaku, así como en su Tipo VI a "creaciones localistas". Al mismo tiempo, estableció dos centros de manufacturación (Zona I o San Pedro de Atacama, y Zona II o Calama-Caspana-Chiuchiu), cada uno de estos centros con tabletas de distinto formato. En la Zona I se concentrarían las "tabletas de mango de sección planiforme en abanico" (su Tipo II, al cual reconoce como de influencia Tiawanaku), mientras que en la Zona II sería mayoritaria la presencia de "labrados tridimensionales" con recurrentes formas de seres antropomorfos (su Tipo VI). Aunque este autor no define estilísticamente a los tallados de la Zona II, establece una diferencia espacio-geográfica básica para estos dos tipos, punto que será de utilidad en la definición estilística que me propongo en el presente artículo.

Torres también insistió en las diferencias técnicas que se observaban en la fabricación de estos recipientes para el cebil (Anadenanthera colubrina var. cebil) en polvo, y estableció los siguientes grupos: a) grupo de piezas rectangulares no decoradas; b) grupo con talla incisa o en bajo relieve; y c) grupo con tallas volumétricas; a estas últimas les asignó -al igual que Núñez- distinta presencia geográfica al interior del área en cuestión (Torres 1986). Paralelamente, del estudio de Thomas y Benavente -basado en un análisis de correspondencia de rasgos morfológicos- se desprendió igualmente que en la localidad de Caspana no había tabletas de estilo Tiawanaku (Thomas y Benavente 1984).

En las décadas siguientes, surgieron investigaciones orientadas a establecer la especificidad de lo "atacameño" entre las tabletas y demás elementos del complejo alucinógeno. Aquí hay que destacar los aportes de Llagostera (1995, 2001), Llagostera et al. (1988) y Hermosi$1 \mathrm{la}(2001)$, quienes hicieron interesantes planteamientos respecto a estilo y secuencias cronológicas al interior de la parafernalia alucinógena. Hermosilla, por su parte, profundiza en la iconografía de las tabletas del cementerio Los Abuelos de Caspana, arribando a conclusio- 
nes iconográficas muy cercanas a las mías; al mismo tiempo, haciendo un análisis de correspondencia entre tabletas y estilos cerámicos, logra demostrar que el material arqueológico de dicho cementerio se ubica entre el 900-1200 DC, y que artefactos del período Medio se encuentran completamente ausentes de su registro (Hermosilla 2001: 128). ${ }^{5}$ Hay que destacar que esta investigadora intenta una reconstrucción de "los rituales sugeridos por la evidencia pictórica" de los elementos alucinógenos (Hermosilla 2001: 123).

Tomando como base la información previa acumulada por la investigación en el tema, mi objetivo es demostrar que hay suficientes datos para definir estilísticamente a un grupo de tabletas bastante numeroso, que presenta un conjunto de características técnicas y temáticas homogéneas; dichas características las alejan definitivamente de las configuraciones del arte Tiawanaku, y por tanto, definen un estilo propio que parece ser básicamente posterior a dicha influencia altiplánica en la región atacameña. ${ }^{6}$ En la definición de este nuevo estilo no solo utilizaré tabletas para inhalar el polvo del cebil, sino también tubos inhalatorios, pilones y espátulas o cucharillas, ya que coincido con el planteamiento de Krapovickas (1958-59: 74) en cuanto hay una evidente unidad estilística entre unos y otros, además de provenir en muchos casos de los mismos contextos funerarios.

Este estudio se nutre de dos disciplinas: de la Arqueología y su información contextual, así como de la Historia del Arte y su recurso metodológico del análisis estilísti-

5 El material excavado por el ingeniero Emil de Bruyne en los años sesenta en la mencionada localidad se encuentra actualmente depositado en el Museo Nacional de Historia Natural de Santiago; originalmente, consistía en 44 ajuares funerarios con 173 artefactos, incluyendo 51 tabletas y 27 tubos (Hermosilla 2001: 128). La tesis de licenciatura de Alliende (1981) es hasta el momento el análisis más detenido sobre dicha colección; recientemente, el estudio de Ayala y colaboradores (1999) sobre la colección arqueológica del cementerio de Los Abuelos depositada en el Museo de Caspana complementa y amplía el tema.

6 Este grupo corresponde en parte al Tipo VI planteado originalmente por Krapovickas (1958-59) y adaptado luego por Núñez (1963); por otra parte, también corresponde al "estilo pre-Tiwanaku" esbozado por Llagostera en su trabajo de 1995.

7 Para el caso de Caspana, por ejemplo, en prácticamente todas las tumbas del cementerio Los Abuelos se encontraron tubos acompañando a las tabletas (Alliende 1981; Hermosilla 2001). co e iconográfico; con este último he abordado la observación de un gran número de elementos del complejo alucinógeno depositados en diversos museos, chilenos y extranjeros (Museo de Historia Natural de Santiago, Museo de Artes Visuales de Santiago, Museo Francisco Fonck de Viña del Mar, Museo R. P. Gustavo Le Paige S. J. de San Pedro de Atacama, Museo Regional de Iquique, Museo de América de Madrid, Museo Arqueológico San Miguel de Azapa, Museo Etnográfico J. B. Ambrosetti de Buenos Aires, Museo Dr. Eduardo Casanova de Tilcara, Museo Arqueológico Provincial de Jujuy, Museo de Antropología de Salta y Musée du quai Branly en París). A partir de dicho análisis propongo la existencia de un estilo de tallas en madera que he denominado como Circumpuneño, debido a su amplio campo de dispersión, cuyo eje es el Trópico de Capricornio e involucra la subárea en torno a la Puna de Atacama; dicha subárea incluye en el norte de Chile la costa de Atacama, la cuenca del río Loa, el salar de Atacama, y en Argentina, la Puna de Jujuy y la quebrada de Humahuaca (Figura 1 y véase Apéndice 1 con la muestra analizada). ${ }^{8}$

Mi intención ha sido retomar la idea original de Krapovickas en cuanto a que nos encontramos frente a un estilo distinto al de Tiawanaku, definir lo más claramente posible en qué se diferencia de tal estilo, y cuáles son las razones que permiten considerarlo como un estilo aparte. Para ello he aplicado el concepto del análisis iconográfico integral propuesto por González y Baldini (1991), incluyendo el mayor número posible de imágenes del universo iconográfico de las tallas alucinógenas conocido actualmente para la subárea en cuestión. La muestra alcanza los 151 objetos entre tabletas, tubos y espátulas, los cuales fueron examinados detenidamente con el objetivo de detectar recurrencias de ciertas combinaciones de elementos en sus respectivas iconografías, o por el contrario, la omisión reiterada de ciertos elementos en determinadas combinaciones (sensu Torres 1983, 2001a). Igualmente he puesto atención especial en la observación de la gestualidad y la postura de las figuras, tanto antropomorfas como zoomorfas.

8 Tal como se puede observar en la Figura 1, el núcleo duro de la dispersión del estilo es el área circumpuneña, con presencia esporádica en el extremo norte de Chile (Arica, Iquique), así como en el Norte Chico (Copiapó, Caldera). 


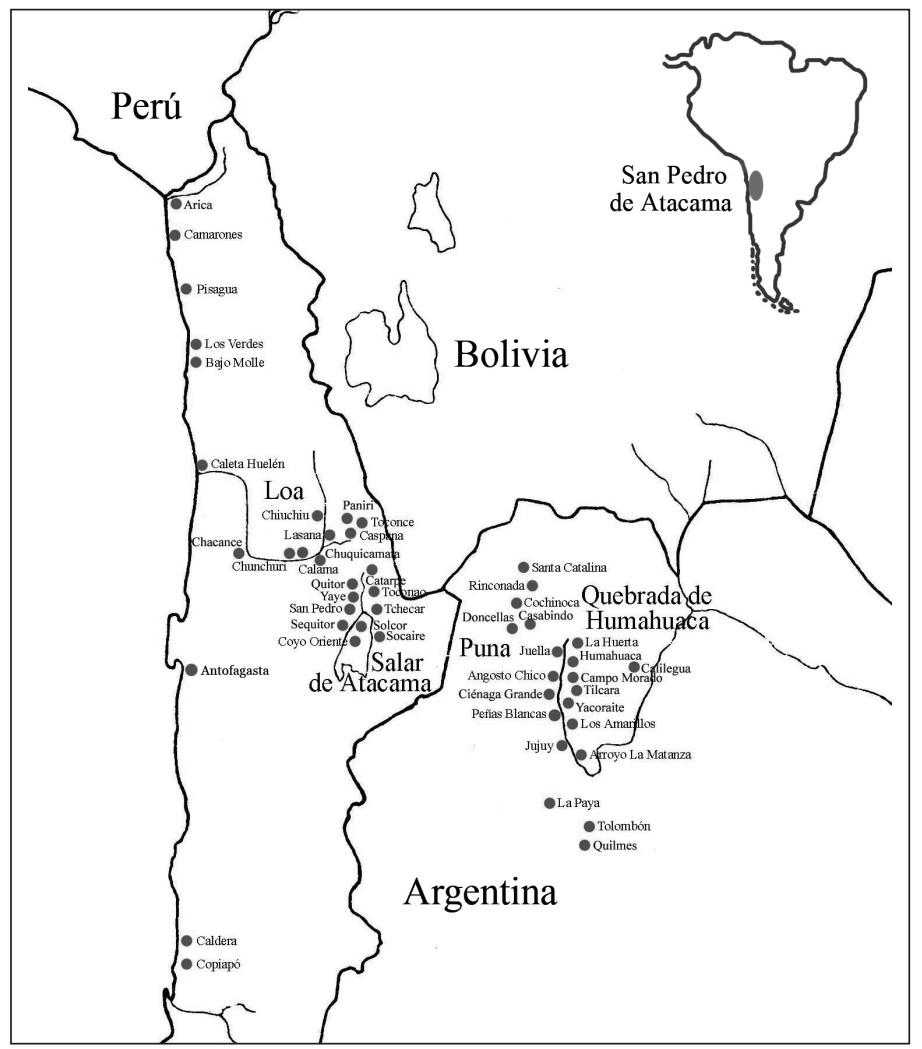

Figura 1. Mapa con los sitios mencionados en el texto y con la ubicación de las áreas con presencia de parafernalia alucinógena de estilo Circumpuneño.

\section{* Rasgos formales y técnicos del estilo Circumpuneño}

Tal como ya lo plantearan los tres investigadores mencionados en el párrafo anterior, la técnica utilizada en la fabricación de este grupo de tabletas es la talla volumétrica o tridimensional del panel. ${ }^{9}$ Por otra parte, la plasticidad de las formas obtenidas por medio de la tridimensionalidad hace al arte de pequeño formato de estas tallas especialmente interesante para el arqueólogo o el historiador del arte, puesto que permite reconocer en sus múltiples

\footnotetext{
9 Entendiendo en este caso la tableta como una suerte de bandeja pequeña de madera con: a) cavidad rectangular, hiperboloide y excepcionalmente ovalada o circular, la cual posee una depresión con un marco de rebaje en todo su contorno donde se depositaba el polvo alucinógeno, y b) un panel a continuación de la cavidad contenedora que podía ser decorado con incisiones o tallado con diferentes niveles de profundidad, alcanzando incluso lo volumétrico y tridimensional.
}

detalles objetos muy icónicos, con claros referentes en la naturaleza o en el entorno social mismo (instrumentos utilizados, vestimentas y tocados, etc.). Al mismo tiempo, en este "arte en miniatura" es posible observar una suerte de narración o relato, lo cual es poco frecuente en el arte prehispánico andino en general, situación que ofrece posibilidades impensadas para el análisis y la interpretación. También es un rasgo propio de este estilo la inclusión de incrustaciones de pequeños trozos rectangulares o circulares de malaquita y otras piedras, en el marco de contorno de la tableta o también en detalles interiores de las figuras talladas en los paneles.

Como se verá a continuación, en el universo iconográfico de este estilo destacan dos tipos de seres básicos: antropomorfos y el felino, cuyas características se combinan generando Antropomorfos Simples, Antropomorfos Complejos y Antropomorfos Felinizados. La fusión de rasgos humanos y felínicos es ampliamente conocido en 


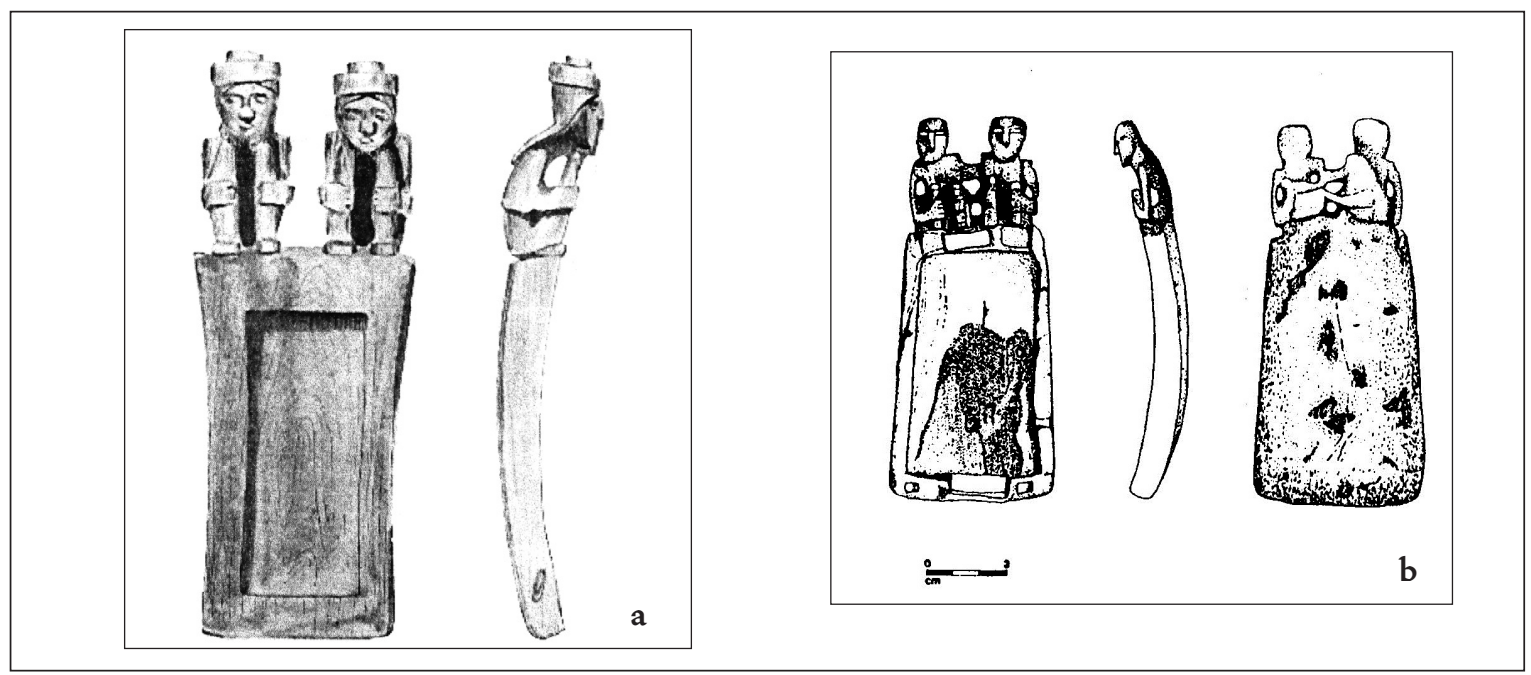

Figura 2. Representaciones de Antropomorfos Simples. a) Dos Antropomorfos Simples. Tableta 1999.1.177 de Chunchurí, Calama (tomado de Oyarzún 1979: Fig. 6). b) Dos Antropomorfos Simples abrazados. Tableta 1999.1.173 de Chunchurí, Calama (tomado de Durán et al. 2000: Fig. 67).

el arte prehispánico andino. Pero en este caso, hay algunas variantes que llaman la atención, y que probablemente se encuentren relacionadas con creencias e ideologías circumpuneñas que analizaremos en detalle más adelante. De la combinación de los elementos humanos y felinos han surgido tres categorías que no eran apreciables a simple vista, y que solo han podido ser establecidas luego de una detenida observación de las configuraciones en las que aparecían. La principal dificultad fue definir la verdadera naturaleza de los personajes retratados, puesto que se trata de un lenguaje altamente simbólico, donde los límites entre diferentes esencias corporales se diluyen.

\section{Rasgos formales de las figuras antropomorfas}

Quizás el rasgo más característico del tallado de la cara humana sea una línea continua que une a las cejas con la nariz; al mismo tiempo, dicha línea produce depresiones que señalan las cuencas de los ojos, a la vez que se ensancha hacia abajo generando una nariz de formato triangular. Este rasgo estilístico fue advertido tempranamente por Krapovickas (1958-59). ${ }^{10}$ La boca -cuando

${ }^{10}$ Este autor define al rostro humano simple de la siguiente manera: "está formada por el contorno de la cara, las cejas y la nariz, todo ello en un relieve continuo. La faz aparece en un plano inferior" (Krapovickas 1958-59: 77). es indicada - es un excavado en la madera de forma subrectangular o circular. Los brazos no presentan mayores modulaciones en el tallado; el tronco es rectangular y la cara ovalada. El pelo se indica cayendo atrás por la espalda como incisiones paralelas diagonales. Cuando la figura antropomorfa se encuentra arrodillada, las plantas de los pies se pueden observar talladas en el reverso de la pieza (esto es válido tanto para las tabletas como para los tubos insufladores); en el caso de la otra posición frecuente, la acuclillada, el personaje es retratado asiendo sus pantorrillas. Esta es probablemente la actitud más característica de las figuras antropomorfas de este estilo (rasgo observado tempranamente por Uhle en 1915). De acuerdo con las posibilidades de combinar lo humano con lo felino, tenemos en este estilo diferentes formas de representación:

1. Antropomorfos Simples. El personaje representado es un ser humano, sin combinación ninguna con rasgos felínicos.

1.1 Uno, dos o tres seres antropomorfos mirando hacia el frente, asiéndose con las manos las rodillas o las pantorrillas (Figura 2a).

1.2 Dos antropomorfos mirando hacia el frente con los brazos enlazados por detrás de la espalda y con la 
mano libre asiendo sus respectivas pantorrillas (Figura 2b).

1.3 Series de una, dos o más cabezas humanas.

2. Antropomorfos Complejos. Aquí nos encontramos con antropomorfos que en ocasiones portan máscaras de felinos sobre sus rostros:

2.1 Antropomorfo(s) sin máscara de felino actuando en rol de Sacrificador.

2.2 Antropomorfo(s) con máscara de felino sobrepuesta a su propia cabeza actuando en rol de Sacrificador (Figura 3a).

2.3 Antropomorfo en rol de Sacrificador-Antarista, con cabeza cortada en una mano y antara (flauta de pan) en la otra, a la altura de la boca (Figura $3 \mathrm{~b}$ ). Existe una variante de este Antropomorfo Complejo, en la cual el Sacrificador-Antarista porta hacha y flauta de pan; esta última parece reemplazar a la cabeza cortada.

2.4 Dos antropomorfos con o sin máscara de felino actuando en rol de Sacrificador (Figura 3c).

Por "rol de Sacrificador" entiendo al personaje humano participante de una escena compuesta por uno o dos antropomorfos hincados en sus rodillas, con o sin máscara de felino sobre su propia cara, que además llevan los atributos clásicos de su función (hacha en una mano y cabeza cortada en la otra), y que a su vez lucen una vestimenta especial compuesta de faja con diseños geométricos, y en algunos casos un tocado especial en forma de gorro redondo o bonete, gorro decorado con diseños geométricos o simplemente el pelo largo cayendo por la espalda. Esto quiere decir que los atributos del Sacrificador incluyen vestimenta, instrumentos y posición corporal especial, cada uno de los cuales lo invisten de su especial poder. ${ }^{11}$ En el estilo Circumpuneño la máscara de felino confiere al antropomorfo su carácter de Sacrificador, en for-

\footnotetext{
${ }^{11}$ Varios de estos atributos fueron advertidos inicialmente por otros investigadores y mencionados en la literatura relacionada con el tema (Krapovickas 1958; Núñez 1962, 1963, entre otros). Por otra parte, Latcham (1962), Mostny (1952; 1968-69), y Núñez (1964) formularon definiciones del Sacrificador y sus atributos estables en relación con el material del Norte Grande de Chile.
}

ma semejante a como ocurre en el arte Tiawanaku (y por extensión en el arte Pucara y Wari), en donde -aunque no siempre se aprecia la máscara como tal- la boca del personaje antropomorfo es felínica con colmillos entrecruzados.

3. Antropomorfos Felinizados. Esta categoría reúne todas aquellas figuras humanas con cabeza de felino que son talladas de perfil y sentadas en cuclillas, y que no suelen presentar los atributos del Sacrificador (túnica y faja; hacha y cabeza cortada).

3.1 Dos antropomorfos felinizados enfrentados (Figura 4a).

3.2 Antropomorfo felinizado flanqueando a Antropomorfo Simple (Figura 4b).

Esta categoría de representación no aparece nunca asociada a vestimenta reconocible, ni tampoco incluye hacha o cabeza cortada, puesto que la única posición corporal observada en ella es la acuclillada con las rodillas asidas por las manos (tal como lo hacen los seres Antropomorfos Simples).

Las representaciones detalladas en los párrafos superiores pueden parecer muchas y variadas, pero en realidad giran - de una u otra forma- en torno a solo dos personajes: el Antropomorfo Simple y el Antropomorfo Complejo, y a un tema central que parece ser el sacrificio o corte de cabezas humanas. Tal como fuese señalado en su momento por Núñez (1962: 48-51), esto habría ocurrido al interior de un rito específico, en el cual los dos protagonistas habrían sido - por un lado- el sacerdote/chamán bajo los efectos alucinatorios producidos por el polvo de cebil inhalado, luciendo la máscara que simboliza a su alter ego, el felino, ${ }^{12} \mathrm{y}$-por otro lado- la víctima humana. Las imágenes que se pueden observar en ciertas tabletas, tubos inhaladores, espátulas, cucharillas, pilones y cajitas de madera y hueso, provenientes de distintos cementerios y sitios excavados en la subárea Circumpuneña permiten hacernos una idea un poco más precisa -aunque por cierto, nunca del todo completa- acerca de este rito.

\footnotetext{
${ }_{12}$ Sobre la identificación de la especie vegetal utilizada véase Pérez Gollán y Gordillo 1993; Torres et al. 1991; Torres 1998; Pochettino et al. 1999).
} 


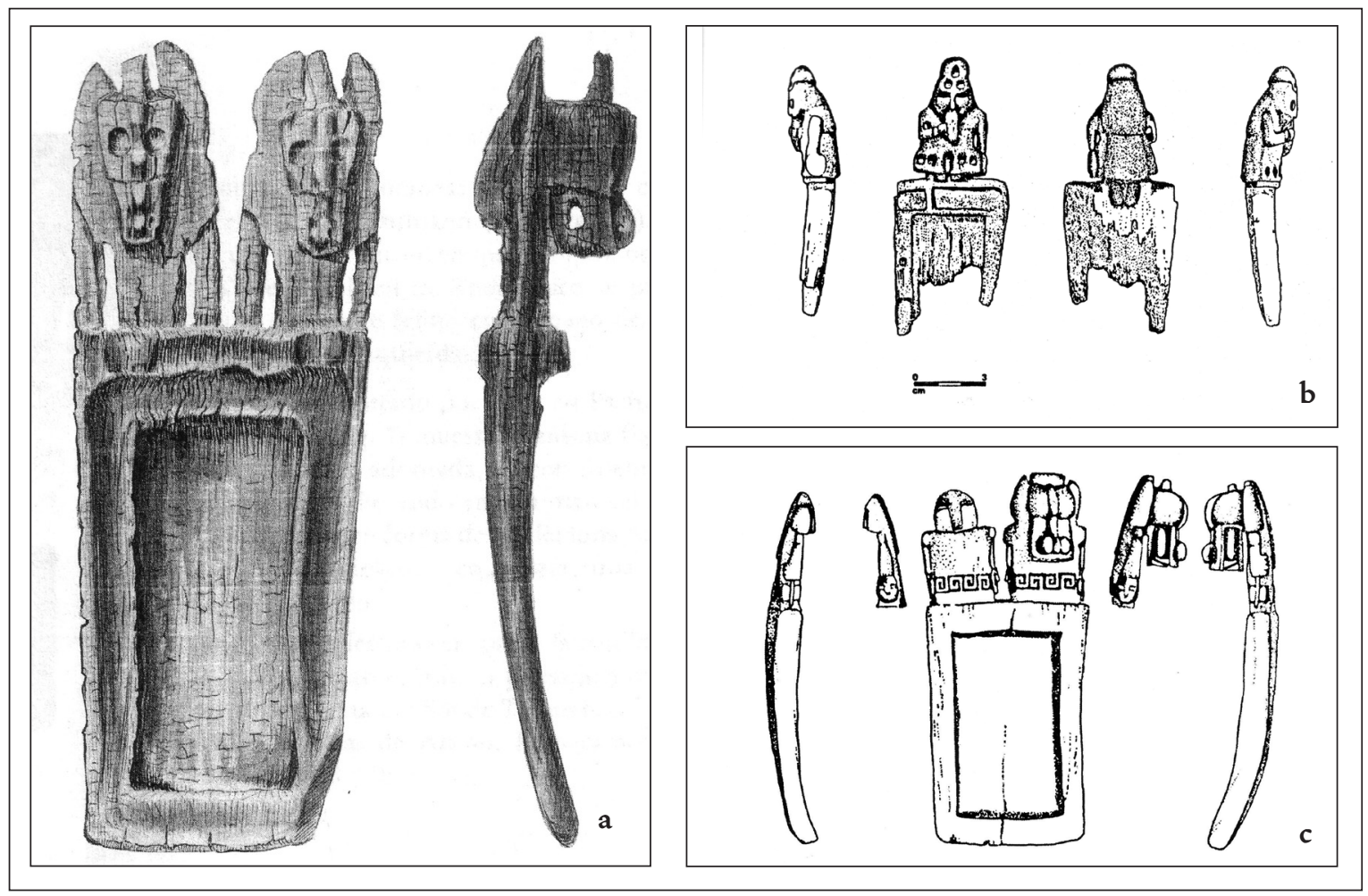

Figura 3. Representaciones de Antropomorfos Complejos. a) Dos Antropomorfos Complejos con máscaras. Tableta 4418 de Chunchurí, Calama (tomado de Oyarzún 1979: Fig. 7). b) Sacrificador-Antarista. Tableta 1999.1.178 de Chunchurí, Calama (tomado de Durán et al. 2000: Fig. 71).c) Dos Antropomorfos Complejos con y sin máscara. Tableta 1999.1.180 de Chunchurí, Calama (tomado de Durán et al. 2000: Fig. 56).

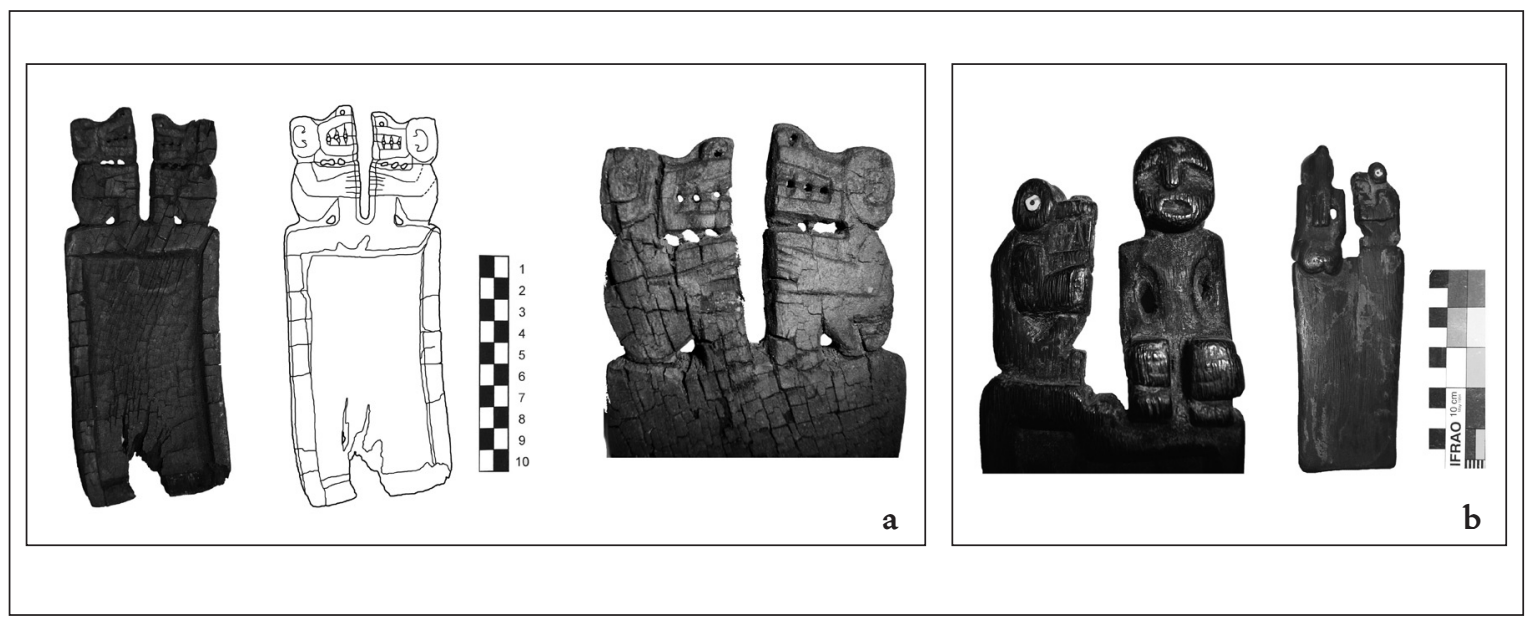

Figura 4. Representaciones de Antropomorfos Felinizados. a) Dos Antropomorfos Felinizados de perfil enfrentados, en posición sedente. Tableta 34.181 de Santa María (Catamarca); Museo Etnográfico J. B. Ambrosetti, Buenos Aires (dibujo de Tania Basterrica basado en fotos de la autora). b) Antropomorfo Simple flanqueado por Antropomorfo Felinizado. Tableta 2565 sin procedencia conocida; Museo Chileno de Arte Precolombino, Santiago (fotos de la autora). 
El felino no es el protagonista principal de esta iconografía -tal como se verá más adelante-, sino más bien su representación se encuentra estrechamente ligada a los dos tipos de figuras antropomorfas que aparecen cumpliendo roles específicos: por un lado, al de Sacrificador, y por otro, al de "Custodio" de víctimas. Por tanto, se puede afirmar que la representación del felino se concentra en la cabeza (o máscara) de dicho animal: su forma es rectilínea, presenta un morro desarrollado, ojos redondos sobresalientes y fosas nasales dilatadas (véanse Figuras $3 a$ y $3 c$, entre otras).

\section{Caracterización del Antropomorfo Simple}

Estos personajes incuestionablemente humanos suelen ser tallados como figuras frontales, en una posición acuclillada característica, aunque cuando participan en composiciones tipo tríada, pueden aparecer excepcionalmente erguidos, tal como se verá más adelante; en ocasiones, la cara toca las rodillas y lucen tocados o arreglo del cabello semejantes a los usados por los Antropomorfos Complejos, pero no túnicas ni fajas que delaten un estatus especial. Incluso en una buena cantidad de casos, ha sido posible precisar que los personajes acuclillados se encuentran desnudos, a juzgar por la línea de nalgas que se indica en la parte baja de sus espaldas, situación no detectada en relación con los Antropomorfos Complejos (véase la Figura 4b, vista posterior). A pesar de la eventual desnudez de estos seres humanos, se ha podido observar que sí pueden lucir símbolos asociados al sacrificio mismo (flauta de pan y símbolo doble-ancla), tal como se expondrá en detalle más adelante. La pasividad expresada en la posición corporal nos permite reconocerlos tanto en las tabletas con figuras individuales, como en aquellas de antropomorfos que flanquean a la figura central de ciertas escenas en tríadas. Aquí hay que resaltar el vínculo aún más sutil que ya pudimos observar en una tableta de Chunchurí (véase Figura 2b), que nos muestra a dos de estos antropomorfos en la posición acuclillada habitual, aunque solo con una mano aferrada a la pantorrilla, porque con la otra se encuentran abrazados por la espalda. Este gesto nos permitirá igualmente vincular más adelante a estas figuras antropomorfas simples con los Antropomorfos Complejos de las tríadas.

\section{Caracterización del Antropomorfo Complejo}

Tal como se adelantó, Antropomorfos Complejos son todos aquellos personajes que son retratados arrodillados o erguidos, y que además presentan atributos complejos como túnica con faja decorada, distintos tipos de tocados o gorros y símbolos especiales asociados (véanse las Figuras 3 a y $3 b$ ). Frecuentemente ocupan el lugar central de las composiciones tipo tríadas, y en conjunto deben ser considerados en esta iconografía como personajes de alto rango o que cumplen un rol de gran importancia.

\section{Caracterización del Antropomorfo Felinizado}

Se trata de un ser humano representado de perfil, con cabeza de felino, sentado en cuclillas con las manos asiendo sus rodillas; su naturaleza humana se verifica por el hecho de no poseer cola ni tampoco patas de animal con garras (véanse Figuras $4 \mathrm{a}$ y $4 \mathrm{~b}$, entre otras). En esta posición acuclillada y de perfil aparece junto a figuras humanas igualmente acuclilladas, en composiciones tipo tríadas.

\section{Composiciones con Tríadas}

Este es un rasgo muy particular del estilo Circumpuneño, en el cual se integran tres figuras realizando determinadas acciones, para las cuales buscaremos explicación por medio del análisis iconográfico. En términos compositivos podemos destacar las siguientes escenas:

a) Tríada compuesta por un Antropomorfo Complejo ubicado centralmente, erguido con máscara de felino que es flanqueado por dos Antropomorfos Simples acuclillados o erguidos (Figura 5a).

b) Tríada compuesta por un Antropomorfo Simple ubicado centralmente (o en su defecto, una cabeza humana) flanqueado por dos Antropomorfos Felinizados (Figura 5b).

c) Tríada compuesta por un Antropomorfo Simple que toca una antara mientras es flanqueado por dos Antropomorfos Felinizados (Figura 5c).

d) Tríada compuesta por un Antropomorfo Complejo (con o sin máscara de felino), flanqueado por dos Antropomorfos Simples, a quienes rodea por la espalda con sus brazos extendidos (Figura $5 \mathrm{~d}$ ). ${ }^{13}$

\footnotetext{
${ }^{13}$ Nótese que en el caso de la Figura $5 \mathrm{~d}$ por encima de las cabezas de los Antropomorfos Simples se aprecian dos volúmenes que dan la
} 


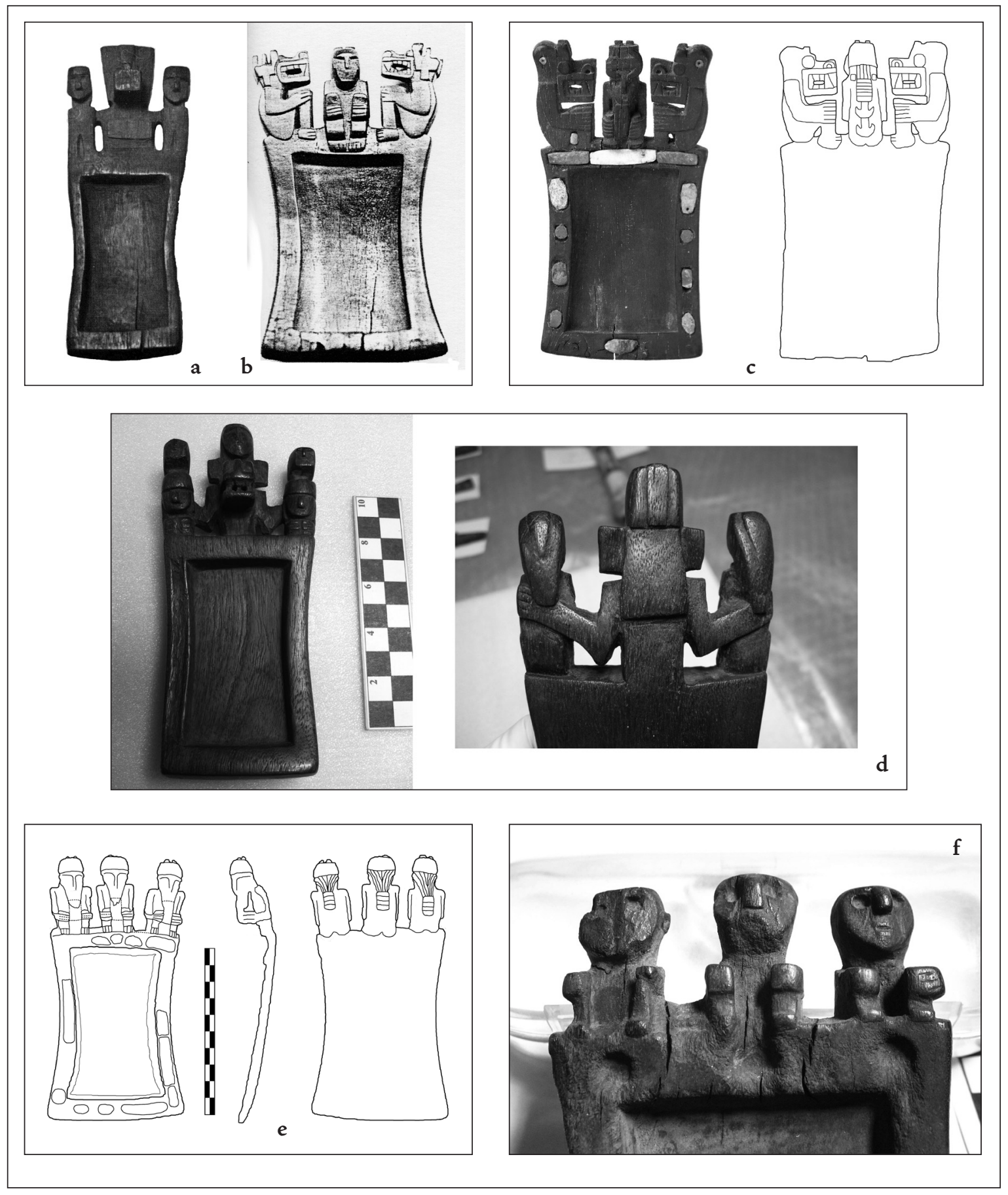

Figura 5. Representaciones de Tríadas. a) Tríada en tableta 17/7960 de Chiu-Chiu; Museum of the American Indian, Heye Foundation, Nueva York (foto gentileza de C. Torres). b) Tríada en tableta 15/1489 de Tolombón; Museum of the American Indian, Heye Foundation, Nueva York (tomado de Torres 1987a: Plate 172). c) Tríada en tableta 9160 de Caspana; Museo R. P. Gustavo Le Paige s.j., San Pedro de Atacama (foto tomada de Pérez de Arce 1995 y dibujo de Tania Basterrica). d) Tríada en tableta de Quilmes, Yocavil; Museo Etnográfico J. B. Ambrosetti, Buenos Aires (fotos de la autora). e) Tríada en tableta 1223 de La Paya; Museo Etnográfico J. B. Ambrosetti, Buenos Aires (dibujos realizados por Tania Basterrica basados en fotos de la autora). f) Tríada en tableta 26.640 de Los Amarillos; Museo Etnográfico J. B. Ambrosetti, Buenos Aires (foto de la autora). 
e) Tríada compuesta por un Antropomorfo Simple ubicado centralmente (de cuerpo entero o como cabeza aislada) flanqueado por dos Antropomorfos Felinizados, cuyas patas anteriores sostienen la cabeza del antropomorfo.

f) Tríada compuesta por tres Antropomorfos Simples tocando antaras (Figura 5e).

g) Tríada compuesta por tres Antropomorfos Simples en cuclillas que no realizan ninguna acción (Figura $5 \mathrm{f}$ ).

\section{Caracterización de las Tríadas}

En el curso de esta investigación se pudo establecer que en la representación de tríadas se dispone con cierta frecuencia en el centro de la tableta a un Antropomorfo Complejo con características de Sacrificador, el cual suele portar máscara de felino o también rodear con sus brazos la espalda de cada una de las figuras humanas que lo flanquean. Estas últimas a veces se hallan ubicadas a un nivel inferior respecto del Sacrificador y suelen tener carácter de humanos comunes y corrientes, sugiriendo la posibilidad de que constituyan las víctimas del sacrificio (véanse las Figuras 5 a y $5 \mathrm{~d}$ ).

En otras ocasiones, el Antropomorfo Simple ubicado centralmente en la tríada sostiene una antara a la altura de la boca o la barbilla, y las figuras acompañantes son seres antropomorfos felinizados, lo cual plantea el vínculo simbólico entre la Víctima-Antarista y el Antropomorfo Felinizado, cada uno como distintos elementos de un mismo guión ritual (véase Figura 5c). Ya mencionáramos en el punto 2.3 a un Antropomorfo Complejo que mientras toca una flauta de pan, en algunos casos

\footnotetext{
impresión inicial de ser otras dos cabezas humanas sobrepuestas, sin relación orgánica con los cuerpos de aquellos, pero la observación detenida de éstas indica que se trata de dos pájaros (¿lechuzas?) posados sobre las cabezas de los personajes laterales. La tableta 12.941 del Museo Histórico Nacional de Santiago presenta esta misma composición de pájaros posados sobre humanos. Por otra parte, la figura central -que en este caso es un Antropomorfo Complejo- presenta a la misma altura de las cabezas de los Antropomorfos Simples una máscara de felino; ésta constituye el elemento volumétrico que más sobresale del perfil de la tableta, y a la vez ocupa el centro del pecho del Sacrificador que la luce. Aquí se trataría del énfasis puesto en el Sacrificador y su máscara.
}

sostiene con la mano libre una cabeza humana, y en otros un hacha (véase Figura 3b). Este caso permite a mi juicio integrar a la cabeza cortada con una cadena compuesta de vínculos simbólicos entre Víctima-Antarista y Sacrificador-Antarista, idea planteada originalmente por Pérez de Arce (2004).

Observando las diferentes convenciones compositivas que se advierten en las escenas de las tríadas, hay que destacar que en el centro siempre ha de figurar un ser antropomorfo frontal (Complejo o Simple, erguido y acuclillado, respectivamente), pero nunca un ser Antropomorfo Felinizado de perfil; por el contrario, los Antropomorfos Simples y los Antropomorfos Felinizados son intercambiables entre sí, esto quiere decir que unos pueden ocupar el lugar de los otros cuando aparecen flanqueando al antropomorfo frontal. No obstante, el canon de representación varía dependiendo de si el ser antropomorfo central es acompañado por Antropomorfos Simples o Felinizados. En el primer caso, la representación es frontal para cada uno de los elementos de la tríada (véase Figura 5a); en el segundo, el antropomorfo mantiene su frontalidad, pero los Antropomorfos Felinizados son retratados de perfil (véase Figura 5b). Esta es otra convención que merece ser destacada: la representación de perfil es exclusiva del Antropomorfo Felinizado, y un alto porcentaje de las composiciones de tríadas corresponden a la configuración "Antropomorfo Felinizado-Víctima-Antropomorfo Felinizado" (véase Apéndice 1.III).

Siempre dentro del tema de las tríadas, también es interesante destacar que - en todas las tabletas que me ha sido posible revisar hasta el momento- no he encontrado ni un solo ejemplar que contuviese al antropomorfo investido de Sacrificador junto al Antropomorfo Felinizado. Aparentemente, se trata de dos conceptos que no pueden coexistir en una misma imagen. Los seres antropomorfos con cabezas de fauces entreabiertas simplemente no aparecen simultáneamente con el Sacrificador, lo cual quizás debiera ser interpretado como que en esencia son lo mismo, tal como será argumentado más adelante. En términos globales, la Víctima se relaciona indistintamente con el Sacrificador o con el Antropomorfo Felinizado; el Sacrificador solo es retratado frontalmente, y el Antropomorfo Felinizado únicamente de perfil. La Víctima, por su parte, siempre es representada frontalmente. 


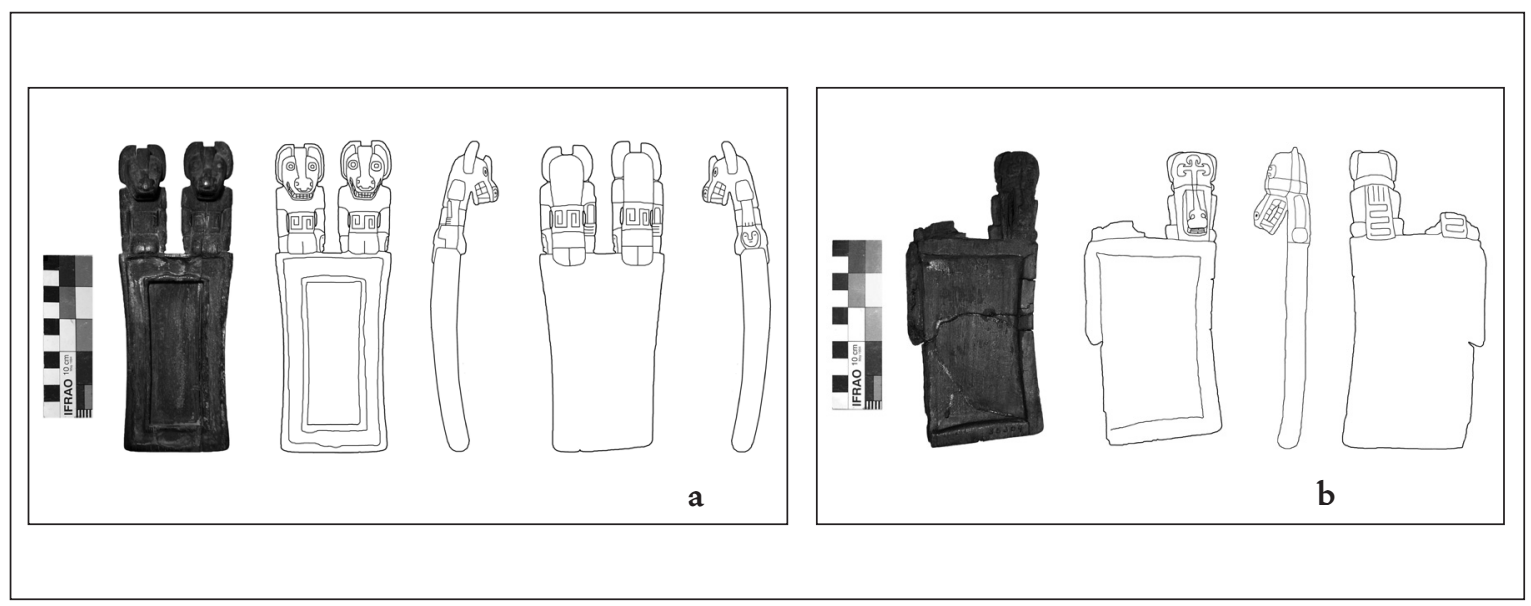

Figura 6. Representaciones del Sacrificador. a) Tableta 1974 sin procedencia conocida; Museo Chileno de Arte Precolombino, Santiago (foto de la autora y dibujos de Tania Basterrica). b) Tableta 22.082 de Tilcara; Museo Etnográfico J. B. Ambrosetti, Buenos Aires (dibujos de Tania Basterrica y foto de la autora).

\section{Composiciones con Dúos}

Tal como ya vimos más arriba, en el estilo Circumpuneño también hay presencia de composiciones duales; son varios los casos en que la talla volumétrica representa a dos personajes con rasgos idénticos o muy semejantes:

- dos Antropomorfos Simples acuclillados y abrazados (véase Figura 2b y Apéndice 1.I)

- dos Antropomorfos Simples acuclillados, uno al lado del otro (tabletas de Chunchurí, 1999.1: 174; 1999.1: 177 (Durán et al. 2000); tableta s/n de Antigal de Ciénaga Grande; tableta 23.072 de Caspana; tableta ovalada 2135 de La Paya; tableta 22.079 de La Paya; véase Apéndice 1.I)

Como era de esperar, también se observan dúos compuestos por Antropomorfos Complejos de vestimenta especial que incluye túnica, gorro y faja con diseño de greca; estos son retratados arrodillados en la gran mayoría de los casos, con los brazos paralelos al cuerpo, no portando nada en las manos. Al mismo tiempo, es destacable la presencia de tabletas y tubos, cuyas composiciones involucran a dúos o personajes individuales arrodillados, igualmente Antropomorfos Complejos vestidos con atuendos especiales, pero a la vez portando objetos en las manos, tales como hacha, cabeza cortada o antara.
En suma, y a la luz del análisis tanto de las composiciones duales como de las tríadas, podemos establecer recurrencia y frecuencia para algunos rasgos. Salta a la vista, por ejemplo, que hay dos posiciones corporales distintas, una en cuclillas y la otra arrodillada, y que cada una se asocia con el uso de vestimenta diferente. Esto quiere decir que los personajes en dúo -o en representación individualque aparecen arrodillados portan vestimenta exclusiva, la cual incluye faja y diferentes tipos de tocados decorados con diseños geométricos. Por el contrario, los personajes acuclillados, sean tres, dos o solo uno, no lucen ni túnica ni faja especialmente distintiva, pero sí tocados con símbolos asociados (gorro con dos orejas y símbolo de doble-ancla, tal como se verá más adelante).

Por otra parte, la idea planteada aquí acerca de que el Sacrificador no es más que un Antropomorfo Complejo con máscara de felino sobrepuesta a su rostro, en una palabra "disfrazado" de tal animal, se ve reforzada por el hecho de que en algunas tallas se puede observar que la máscara cubre por delante la cabeza, pero por detrás queda al descubierto el cabello largo y suelto del antropomorfo (éste en algunas ocasiones parece estar peinado en trenzas delgadas paralelas; véanse las Figuras 6a, 6b y 9). Asimismo, si observamos con atención la Figura $3 c$ podremos apreciar una escena excepcional: se trata de la representación de dos sacrificadores vestidos iguales y con los mismos atributos de la decapitación en las respectivas manos, 


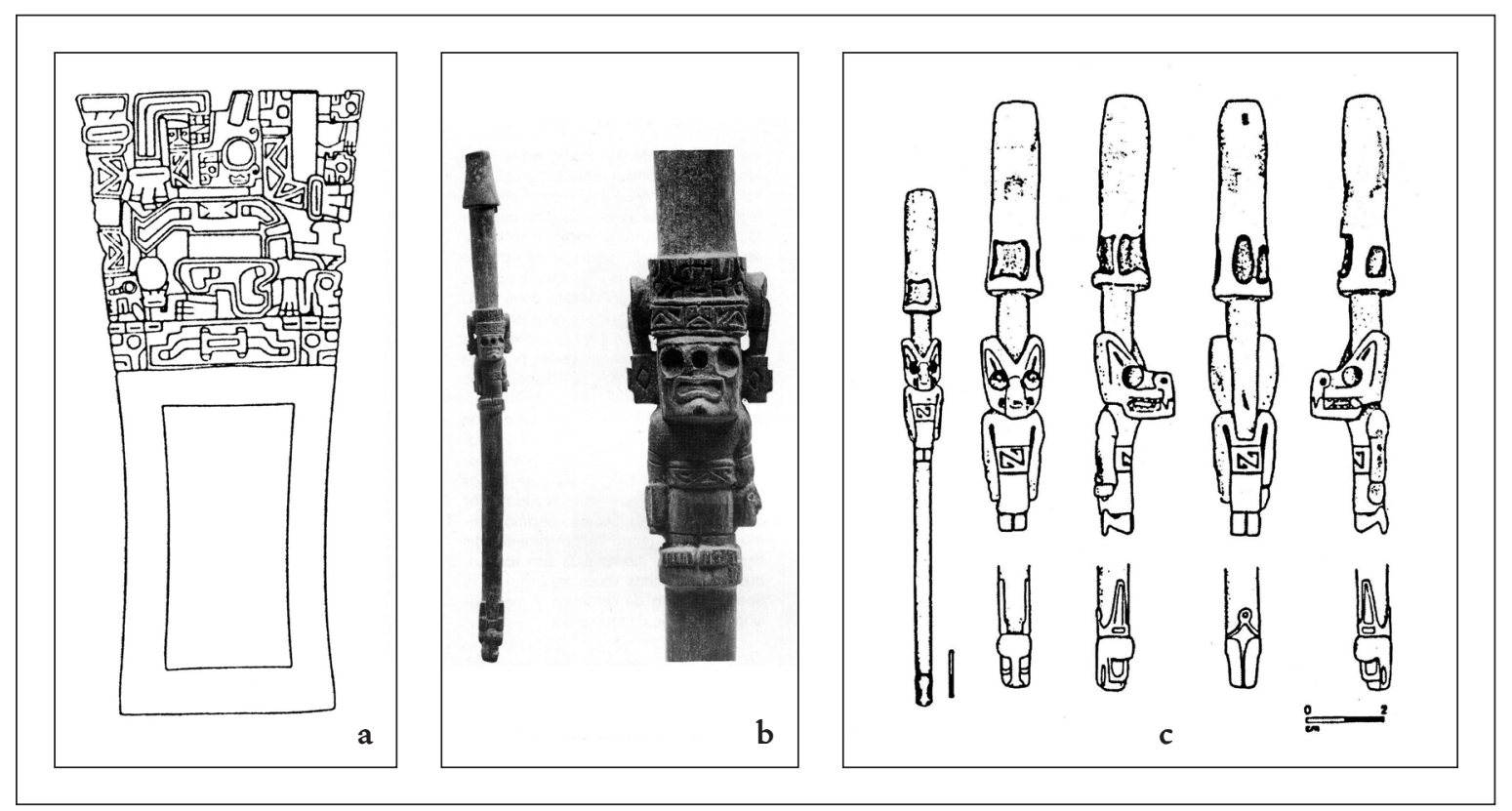

Figura 7. Representaciones del Sacrificador. a) Tableta estilo Tiawanaku 8432 de Solcor-3, San Pedro de Atacama, tumba 107 (tomado de Llagostera et al. 1988: Lám. 8). b) Tubo inhalatorio 2768 de Solcor-3, San Pedro de Atacama, tumba 79 (tomado de Berenguer 1984: 19). c) Tubo insuflador 1999.1.208 de Chunchurí, con Sacrificador Enmascarado (tomado de Durán et al. 200o: Fig. 67).

pero solo uno de ellos porta la máscara de felino sobre su propio rostro, el otro no. El carácter simultáneo de esta representación es muy sugerente, por cuanto corrobora la idea sostenida acerca de que el Sacrificador -en algún pasaje del rito- se enmascara. ${ }^{14}$

Por tanto, hasta aquí se puede plantear como hipótesis a desarrollar a base de otros rasgos que iré presentando a continuación, una posible diferencia de los roles asignados para "acuclillados" versus "arrodillados": los personajes en cuclillas corresponderían a simples mortales, posibles víctimas de un rito que culminaría con el sacrificio humano, mientras que -por el contrario- los personajes de rodillas parecerían cumplir el rol de sacri-

\footnotetext{
${ }^{14}$ Dicho acto de "enmascaramiento" por parte de un antropomorfo con características de Sacrificador ya fue planteado por Mostny (1968-69), en relación con imágenes del arte rupestre del río Loa, señalando la existencia de un complejo religioso integrado por tabletas, tubos y máscaras de felino, así como la creencia en un dios felino que habrían profesado los habitantes de la región. Núñez, igualmente, argumenta en favor de una deidad felina, a quien el "shamán enmascarado" habría presentado sacrificios humanos (Núñez 1962: 49).
}

ficadores de los anteriores. A continuación veremos que hay varios argumentos que refuerzan esta idea.

\section{* Iconografía Tiawanaku versus ICONOGRAFÍa CirCUMPUNEÑA}

\section{Caracterización del Sacrificador Circumpuneño}

Sobre la base de la observación de imágenes del arte Tiawanaku plasmadas en soportes tan diversos como textiles, cerámica, tallas en madera, litoescultura y otros como arte rupestre, creo que se pueden precisar las diferencias entre la manera de representar al Sacrificador tiawanaku y al Sacrificador circumpuneño. Antes de entrar a detallar las diferencias, es necesario reiterar que en ambos casos el protagonista es un ser antropomorfo con características felínicas, ya sea porque tiene dispuesta sobre la cabeza una máscara de felino, o porque es retratado en medio del proceso de transformación de ser humano a felino.

En lo que respecta a las tallas en madera de tabletas, tubos o espátulas, las diferencias apuntan por un lado a al- 
gunos detalles específicos de la gestualidad y la postura corporal, y por otro lado, al uso de determinados atributos. El Sacrificador tiawanaku es retratado generalmente como un personaje semiarrodillado, vale decir, mientras realiza el rito de presentación de la cabeza humana se encuentra con una rodilla en tierra, mientras que con una mano mantiene un báculo (a veces con remate de cabeza cortada), y con la otra mano sostiene simultáneamente el hacha y la cabeza cortada por detrás de su espalda (Figura 7a). Este es el patrón de las tabletas tiawanaku con iconografía tallada en bajorrelieve. Sin embargo, en tres ocasiones excepcionales la talla realizada es volumétrica, y el patrón se modifica, puesto que el Sacrificador se halla de pie sosteniendo con una mano la cabeza al frente de su propio cuerpo, mientras que de la derecha pende el hacha con que decapitó a la Víctima (tableta s/n de Patillos-1, Iquique [Núñez 1967]; tableta 9164 de Quitor-5 [Llagostera 2006a: fig. 5]). El tercer caso es la tableta 9163 también de Quitor-5, en la cual vemos tallado tridimensionalmente al Sacrificador Tiawanaku con una rodilla en tierra, mientras hace la presentación de la cabeza cortada por delante de su propio cuerpo, hacia donde dirige la mirada; a su espalda, a la altura del piso, sostiene el hacha (Llagostera 2006a: fig. 12). En relación con sus representaciones talladas en tubos inhalatorios, lo vemos de pie y no arrodillado, con los brazos colgantes mientras sostiene hacha y cabeza cortada en cada una de sus manos (Figura $7 \mathrm{~b}$ ).

Por el contrario, el Sacrificador circumpuneño se presenta hincado o con las dos rodillas en tierra, en la mayoría de los casos sus brazos cuelgan paralelos al cuerpo presentando igualmente los símbolos del rito: hacha en la mano derecha y cabeza en la izquierda (Figura 7c). Hasta el momento, no he encontrado un ejemplar en donde la cabeza sea presentada y sostenida por el Sacrificador a la altura del pecho, en la postura reconocida para tubos tiawanaku. ${ }^{15}$ Otra diferencia palpable es la total ausencia en este último estilo de algo semejante a un instrumento musical aerófono como es la flauta de pan, y más ajena aún es la idea de que dicho instrumento pudiese ocupar el lugar de la cabeza humana decapitada como contraparte del hacha utilizada en el mismo rito. También he podido constatar otra diferencia en cuanto

\footnotetext{
${ }^{15}$ Este gesto preciso de la presentación de la cabeza cortada ya se observa en la litoescultura Pucara (Mujica 1991: fig. 219).
}

al número de sacrificadores que participan en el rito: en las imágenes tiawanaku se trata invariablemente de un personaje solitario, que investido de todos sus atributos realiza la acción individualmente. Por el contrario, en las tabletas, tubos y espátulas circumpuneñas nos encontramos a menudo con dos sacrificadores, con dos personajes que aparentemente realizan el rito simultáneamente.

En relación con la diferencia de atributos, éstas se concentran en el diferente uso de diseños en la faja. Las evidencias indican que la faja que se sobrepone a la túnica es parte esencial de la vestimenta distintiva del personaje que sacrifica: tanto en el arte Pucara, Tiawanaku y Wari (Cook 1994), así como en el arte de las tallas circumpuneñas se encuentra presente conformando los atributos estables de dicho personaje. La diferencia es que en las imágenes de las artes mencionadas el diseño de la faja es preponderantemente un zigzag horizontal, ${ }^{16}$ o en ocasiones menos frecuentes, un rectángulo concéntrico o un meandro rectilíneo. Por el contrario, para las tallas de sacrificadores circumpuneños el diseño observado recurrentemente es el de una greca o " $Z$ " horizontal (véase detalle de las Figuras 3c, 6a y $7 \mathrm{c}$ ).

Otro aspecto relacionado con la vestimenta es el uso de un tocado distinto; las imágenes de sacrificadores tiawanaku en tabletas poseen un tocado complejo, compuesto de una base en forma de media luna, de la cual surgen diversos elementos pautados según los patrones iconográficos altiplánicos. Entre dichos elementos no es extraño advertir miembros del cuerpo humano, tales como piernas, cabezas o troncos completos (Llagostera et al. 1988: 79; Llagostera 2006a: figs. 11a, b y c), situación que refuerza la identidad de Sacrificador del personaje. Por el contrario, las imágenes de los sacrificadores del estilo Circumpuneño no lucen tocados alusivos al rol que les toca desempeñar en el sacrificio, sino solo un gorro y un peinado complejo cubriendo sus espaldas, que los distinguen en conjunto con la faja decorada con grecas. En general, su parafernalia es mucho más simple que la de las imágenes tiawanaku, pero tanto su gestualidad como postura corporal son más variadas y ricas.

\footnotetext{
${ }^{16}$ Este diseño de zigzag horizontal parece ser tan antiguo como el arte Pucara mismo, si tomamos en cuenta la evidencia de los monolitos de dicho arte (el Sacrificador de Puno [Paredes 1984]).
} 


\section{La aplicación de incrustaciones}

De acuerdo con las observaciones realizadas en la muestra estudiada, planteo aquí que la incrustación de piedras en el marco perimetral de las tabletas corresponde a un rasgo propio del área del río Loa, San Pedro de Atacama y regiones vecinas, y no habría respondido a una costumbre del área nuclear de Tiawanaku, en donde probablemente solo se incrustaban ojos y otros detalles de las figuras ubicadas en los paneles superiores de las tabletas. ${ }^{17}$ En el estilo Circumpuneño esta costumbre se centra fundamentalmente en la aplicación de variadas piedras tales como malaquita, azurita y turquesa (Thomas y Benavente 1984: 168), así como mullu (Spondylus princeps) y nácar en los bordes planos de la tableta que enmarcan el receptáculo o cavidad central; también se incrustan círculos de malaquita en las cuencas de los ojos de humanos y felinos, así como en las fosas nasales u orejas en el caso de representaciones de felinos (véase la Figura 4 b que aún conserva incrustaciones). La revisión bibliográfica apoya esta idea: el ejemplar de tableta de Niño Korin (70.19.1, Museo de Gotemburgo, Suecia [Wassén 1972: fig. 5]), por ejemplo, tiene el marco decorado con incisiones y no con incrustaciones; lo mismo tiene vigencia para el ejemplar en piedra del Museo Etnográfico de Buenos Aires (tableta 10718, al parecer proveniente de Tiahuanaco [Torres 1987a: Plate 16]). Quizás pudiésemos interpretar el hecho de la aplicación de incrustaciones a los marcos de las piezas tiawanaku como el acto de "agregarles valor", o de cierta "apropiación simbólica" por parte de los usuarios locales de éstas.

Finalmente, también hay que destacar que las tabletas con tríadas son las piezas que exhibían más aplicación de incrustaciones, existiendo ejemplares con los bordes de la cavidad casi enteramente recubiertos por piedras de distintos colores y tamaños (véanse Figuras 5c, 5e, 5f, 8 y 10a). Este hecho sugiere la preeminencia de las tabletas con este tipo de composición visual y podría estar señalando el mayor prestigio de éstas al interior de la parafernalia alucinógena circumpuneña, probablemente porque en ellas se habría condensado la ideología del sacrificio humano por medio de la decapitación.

\footnotetext{
${ }^{17}$ Hay que destacar que la tableta de Amahuaya, Bolivia, es una excepción, ya que presenta huellas de incrustaciones rectangulares a lo largo de todo el marco de la tableta, así como incrustaciones de malaquita, bronce, lapislázuli, turquesa y Spondylus princeps todavía in situ en diferentes detalles del personaje tallado (Rendón 1999).
}

\section{* El rito y sus principales actores}

A la luz de las evidencias que nos ofrecen las imágenes analizadas podemos plantear algunas ideas plausibles acerca de una posible "coreografía" ritual que habría sido dirigida por el o los sacrificadores. Esto es especialmente relevante, porque el arte Tiawanaku -en sumo hierático y críptico - no considera la narración de acciones, sus representaciones son abstracciones alejadas de lo real, cargadas de un simbolismo impenetrable. De esta manera, el arte en miniatura de las tallas circumpuneñas resulta ser una fuente inagotable para el desciframiento de ciertos pasajes de antiguos ritos. Ya en 1908 señalaba Ambrosetti en relación con las tabletas del sitio de La Paya (Salta, noroeste de Argentina): "Con estos datos me aferro más en mi creencia de que estas tabletas nos muestran escenas sueltas de alguna ceremonia de carácter religioso, en las que intervinieron entre otras cosas, personas con máscaras representando divinidades o entidades míticas" (Ambrosetti 1908: 507). Los personajes que habrían participado en las escenas de estas ceremonias son los que describo a continuación:

Victimas simples. Son todas aquellas figuras humanas idénticas o muy semejantes presentadas individualmente, en parejas o tríos, que no realizan ninguna acción y en la gran mayoría de los casos se encuentran sentadas con las piernas fuertemente flectadas, mientras que con las manos mantienen sujetas sus pantorrillas (Figura 8). Por lo general el pelo desciende por la espalda en forma triangular con un embarrilado como remate; cuando lucen tocado éste puede ser: a) bonete simple (véanse Figuras za y $5 a), b)$ bonete con dos orejas (véanse Figuras 5b, 5 c y 5 e), o c) bonete con símbolo en forma de doble-ancla (véanse Figuras 5c y 11a).

Victimas Tocando la Antara. Las mismas figuras mencionadas en el párrafo anterior pueden aparecer en ocasiones sosteniendo con las dos manos una flauta de pan, en actitud de tocarla. No creo que se trate de un atributo que marque algún tipo de jerarquía entre las víctimas, sino más bien de diferencias en la secuencia del rito como explicaré más adelante (véanse Figuras 5 c y 5e).

Custodios de las Victimas. Tal parece ser el papel del Antropomorfo Felinizado retratado de perfil; ya se mencionó que es el personaje que flanquea a la Víctima central, y al igual que ella aparece en cuclillas. Por otra parte, en las tríadas 


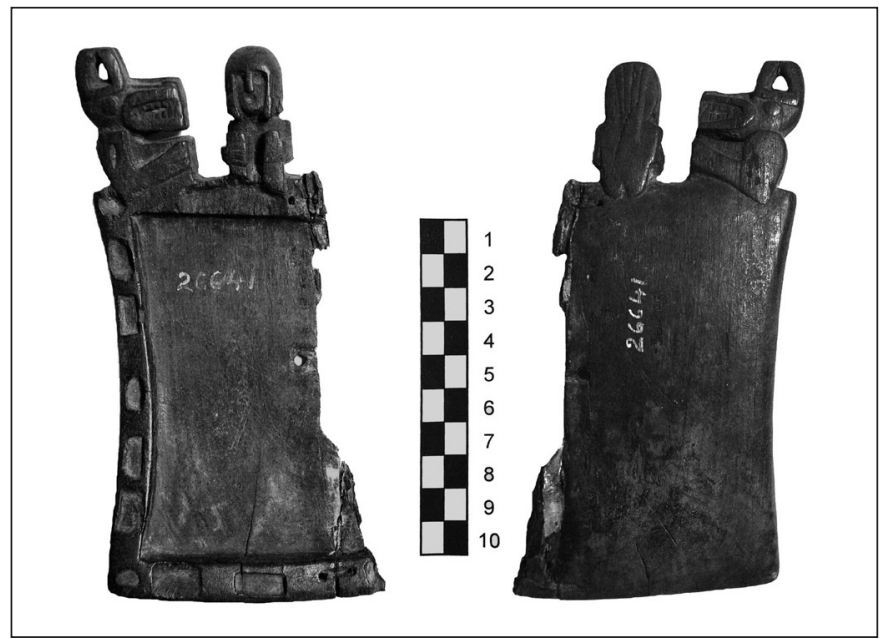

Figura 8. Tableta 26.641 de Los Amarillos con Víctima central flanqueada por dos Antropomorfos Felinizados (uno de ellos hoy ausente); Museo Etnográfico J. B. Ambrosetti, Buenos Aires (fotos de la autora).

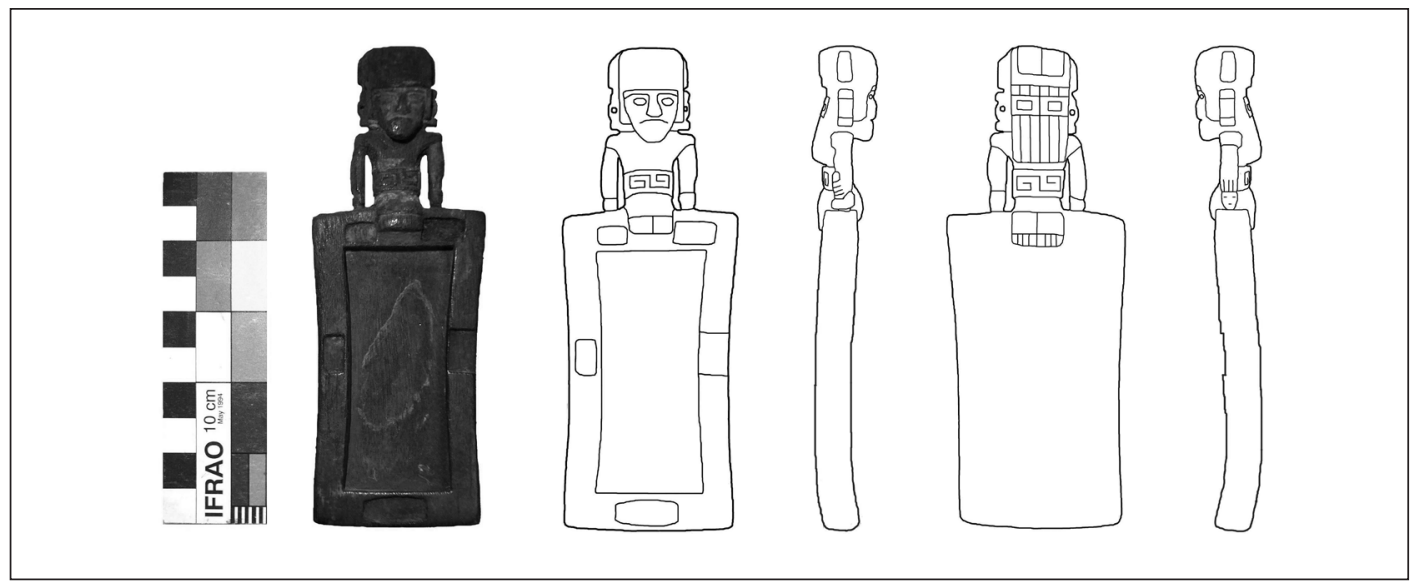

Figura 9. Tableta 1976 sin procedencia conocida; Museo Chileno de Arte Precolombino, Santiago (foto de la autora y dibujos de Tania Basterrica).

estos guardianes laterales no presentan vestimenta especial, solo una máscara prominente que oculta su rostro humano. Lo más decisivo parece ser que -en tanto guardián y no sacrificador de víctimas - son retratados sin los atributos de la decapitación (véanse Figuras 4a, 4b, 5b, 5c y 8).

Sacrificador No-enmascarado. Son todas aquellas figuras humanas presentadas individualmente o en parejas idénticas que se encuentran en una amplia mayoría de los casos hincadas en tierra -aunque hay casos aislados de figuras erguidas-, realizando la acción de portar objetos en las manos (hacha y cabeza cortada; hacha y antara), así como eventualmente tocar la flauta de pan, y lucir además una faja con diseño de grecas (Figura 9; véanse también Figuras $3 \mathrm{~b}, 3 \mathrm{c}$ ). En ocasiones, figuras de estas características no portan los objetos del sacrificio en las manos, pero pueden ser reconocidas como sacrificadores debido a la utilización de la faja o de la postura hincada, rasgos exclusivos de aquellos. En este tipo de representación del Sacrificador no se observa alusión directa a su vínculo con 
el felino, vale decir no porta máscara con fauces felínica, ni orejas erguidas. Basándome en el análisis iconográfico integral de la parafernalia alucinógena, planteo que estas figuras deben ser consideradas representaciones del Sacrificador, aun cuando no porten los objetos del sacrificio ni la máscara de felino.

Sacrificador Enmascarado. Son todas aquellas figuras humanas representadas individualmente o en parejas -en muchos casos idénticas-, que se encuentran hincadas en tierra, realizando la acción de portar objetos en las manos (hacha y cabeza cortada; hacha y antara), luciendo una faja con diseño de grecas y una máscara de felino sobrepuesta al rostro. En ocasiones, figuras de estas características no portan los objetos del sacrificio en las manos, o en lugar de aparecer hincadas se presentan erguidas en dos piernas, pero pueden ser reconocidas como sacrificadores debido a la utilización de la faja o de la postura hincada, rasgos exclusivos de ellos (véanse Figuras $3 a, 3 c, 5 a, 5 d, 6 a, 6 b, 7 c, 9)$.

En suma, las evidencias presentadas demuestran que en ciertos casos se da la conjunción ideal de todos los elementos o atributos iconográficos en una misma imagen (hacha, cabeza cortada, faja con grecas, máscara de felino, postura hincada, flauta de pan supliendo a la cabeza o al hacha) y que en otros solo se da parcialmente, pero que en uno y otro caso, el observador atento podrá descubrir el mismo gran tema del Sacrificador detrás de todas estas formas de apariencia tan sutilmente diferentes.

\section{* El rol jugado por la música en el rito}

En relación con los Antropomorfos Complejos y las Víctimas participantes en escenas de tríadas, ya fue señalada la presencia de flautas de pan o antaras. Esta situación también fue advertida y analizada por el etnomusicólogo José Pérez de Arce, quien -aproximándose al tema de las tabletas desde la búsqueda de representaciones de instrumentos prehispánicos-, ha arribado a conclusiones muy cercanas a las que yo planteo aquí (Pérez de Arce 1982, 1995). Este investigador define a la zampoña o siku como un instrumento de viento construido con un número variable de tubos de caña, unidos por un travesaño de madera o caña y amarrados con cuerdas de fibra de camélido; la antara - por el contrario- corresponde a otro tipo de flauta de pan confor- mado por un bloque de arcilla o piedra, cuyo interior posee orificios en número de tres o cuatro y en la mayoría de los casos estas divisiones internas no se reflejan en el exterior. Además, este autor establece una clara diferencia en la dispersión geográfica del instrumento musical zampoña (área de Arica, extremo norte de Chile) y de la antara (San Pedro de Atacama), destacando a ambos como productos de dos diferentes tradiciones culturales y musicales (Pérez de Arce 1995). Desde el punto de vista iconográfico, el autor mencionado establece la existencia del Tema del Antarista entre representaciones de tabletas, y una variante del mismo: el Tema del Sacrificador-Músico (para los casos en que se observa indistintamente el reemplazo de la cabeza cortada o el hacha por la flauta de pan, tal como ya lo hemos visto más arriba). Ambos temas se encontrarían insertos -siguiendo los planteamientos de Pérez de Arce-, en un sistema iconográfico más amplio, cuyo eje sería un personaje central con rasgos felínicos vinculado a los instrumentos antara y trompeta, así como con el Tema del Sacrificador-Músico. Este sistema iconográfico se relacionaría con la práctica de la inhalación de alucinógenos materializada en tabletas y tubos (Pérez de Arce 2004; véase también Durán 2001).

\section{* El gorro con dos orejas y la vestimenta USADA EN EL RITO}

Otra interesante cuestión es la detección de elementos de la vestimenta que nos permitan profundizar en la definición de los atavíos que exigía el ejercicio de los roles de Víctimas o de Sacrificadores. Un elemento de gran carga simbólica parece haber sido un gorro muy particular, similar a un bonete con orejas o anillos en su parte superior (véanse Figuras 5b, 5c, 5 e y 10a). Tales tocados han aparecido esporádicamente en el registro arqueológico de la zona atacameña, pero hasta aquí no habían sido asociados a un contexto de significación específico. Creo que actualmente, gracias a las evidencias que nos ofrecen las tallas en madera de tabletas y tubos, es posible hacerlo. Torres en su estudio monográfico sobre tabletas mencionaba la presencia de "cuernos" (horns) o cortas proyecciones sobre la cabeza de diversas figuras antropomorfas de tabletas provenientes de Chile y Argentina (Torres 1987a: 98), suponiendo que podrían corresponder a tocados textiles semejantes a los publicados por Llagostera y Costa (1984: fig. 66). Por su parte, Ambrosetti describiendo tabletas de La Paya también apuntó la presencia de "cuer- 


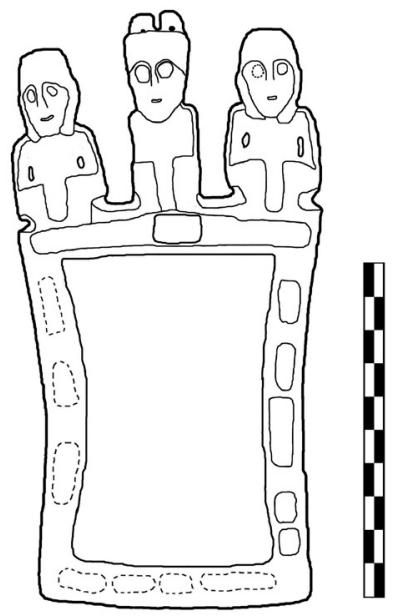

a

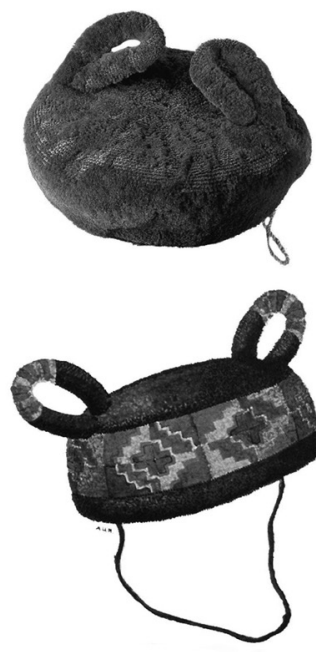

b

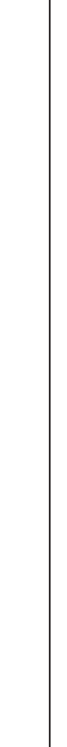

Figura 10. a) Tableta 2228 proveniente del Pucara de Tilcara (dibujo de Tania Basterrica en base a foto publicada en Sin autor 2002a). b) Gorro tipo bonete monocromo con dos orejas proveniente de Solor-3, San Pedro de Atacama (tomado de Berenguer 2007: Fig. 20c). c) Gorro tipo bonete polícromo con dos orejas proveniente de Catarpe-2, San Pedro de Atacama (tomado de Llagostera y Costa 1984: 66).

nitos" sobre la cabeza del personaje central de una tríada (tableta 1600, MEJBA), pero desgraciadamente "cayeron inmediatamente y no fue posible podérselos adaptar de nuevo, porque se deshicieron" (Ambrosetti 1908: 505). Igualmente, en relación con otra tableta (1223, MEJBA; véase Figura 5e) que también exhibe una tríada -en este caso de antaristas-, señaló que presentaban sobre la cabeza "cuernitos semilunares, implantados frente a frente". Efectivamente, en este último caso he tenido la posibilidad de comprobar que se trata de un tocado con dos protuberancias en el centro, al igual que en los casos del personaje central de las Figuras 5 b y 5 c.

Respecto a los ejemplares arqueológicos de tocados que podrían corresponder a los retratados sobre las cabezas de los personajes de las tabletas mencionadas, contamos con un número reducido de gorros con orejas provenientes de la zona del Loa y del salar de Atacama. La literatura especializada los ha denominado "gorro afelpado tipo boina" (Agüero 2000), o "boina aterciopelada" (Berenguer 2007), y su técnica corresponde al anillado con inserción de mechas que luego son cortadas a ras (simili velours; Izikowitz 1933; Latcham 1938: 285). Por su parte, Llagos- tera y Costa los mencionan como gorros con apéndices "que simulan orejas de felino" (1984: 66). Núñez, por su parte, describiendo una pequeña estatuilla de madera ("Shamán de Pica"), menciona el uso de un "sombrero" que ajusta a un "capuchón" con dos orejas felinas; según la nueva luz arrojada por la iconografía alucinógena considero que podría tratarse más bien de un gorro afelpado con dos orejas (Núñez 1961, 1962: 197, fig. 33).

Cuando Tarragó estableció en 1989 la primera secuencia textil para los oasis del salar de Atacama, señaló a los gorros afelpados (con y sin orejas) como elementos de ajuares funerarios asociados a cerámica Negra Pulida y cerámica Tiahuanaco. Sin embargo, la revisión de la textilería atacameña que ha realizado recientemente Agüero (2000) le ha permitido incluir en la Fase Yaye de San Pedro (950-1200 DC) a dos de dichos gorros sin decoración provenientes de Solor-3 (vemos a uno de ellos en la Figura 1ob), así como a otro ejemplar, esta vez con decoración geométrica policroma (Figura 10c), que fue registrado en el material de Catarpe-2 perteneciente a la Fase Solor, posterior a la Fase Yaye en la secuencia sanpedrina (1200-1470 DC) (Agüero 2000, quien se basa en 


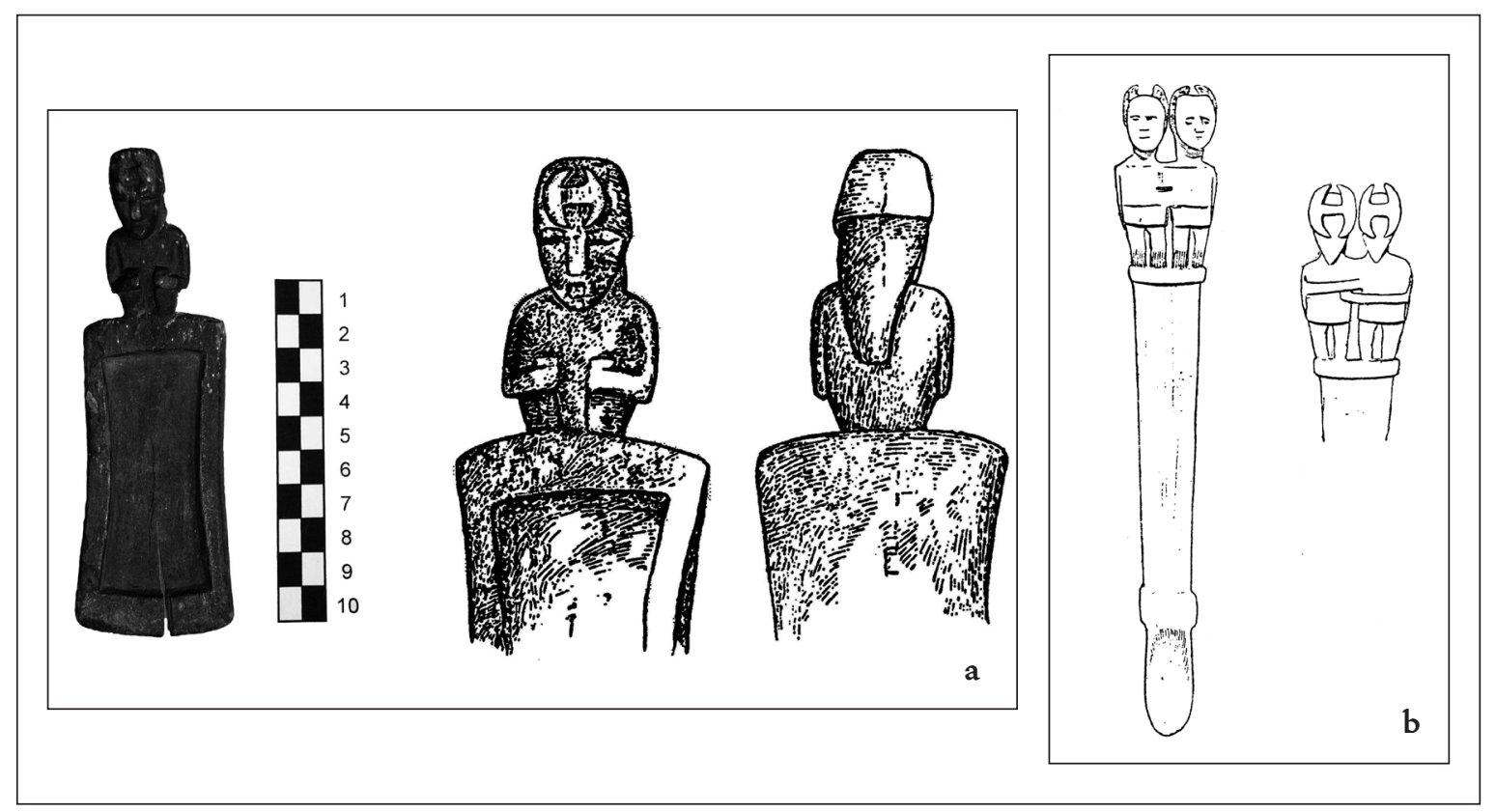

Figura 11. a) Tableta 43-112 de Doncellas; Museo Etnográfico J. B. Ambrosetti, Buenos Aires (dibujos tomados de Torres 1987a: Plate 155). Foto de la autora. b) Espátula de madera proveniente del Pucara de Rinconada, Jujuy (tomado de Torres 1987a: Plate 154).

el orden cronológico-cultural propuesto por Tarragó en 1989). Aparte de estos ejemplares con contexto, también se conoce un ejemplar decorado de la tumba 5 de Chacance 2, tramo medio del río Loa (núm. 810118; Sin autor 2002; Agüero 2007). ${ }^{18}$ Tanto en el caso de Solor como Catarpe, estos bonetes aparecen con una frecuencia muy inferior a la de los gorros de piel con armazón de paja, el cual constituye el tocado identitario de los atacameños durante el período Intermedio Tardío (Agüero 2000, 2007). ${ }^{19}$ En mi opinión, esta situación destaca el carácter

\footnotetext{
${ }^{18}$ Conviene destacar aquí el carácter excepcional del entierro número 5 de Chacance-2 en términos de la variedad, cantidad y calidad de los objetos incluidos en él. Agüero entrega la lista pormenorizada de su ofrenda, la cual incluye simultáneamente otros dos tocados cefálicos, una túnica muy poco frecuente con la técnica del teñido por amarras, entre otros bienes funerarios de élite (Agüero 2007: 137).

19 Del material proveniente de las 35 tumbas de Solor-3, Agüero (2000) da cuenta de 17 gorros de piel $(48,5 \%)$ y de dos gorros afelpados con orejas (6\%); de las 329 tumbas de Catarpe-2 provienen 59 gorros de piel (18\%), contra cinco gorros afelpados, pero tan solo uno con orejas (1,5\%). Recientemente, he podido indagar más sobre la presencia de estos gorros afelpados en relación con otros cementerios del salar de Atacama. Es el caso de
}

excepcional del tocado en forma de bonete con apéndices tipo oreja redonda, y lo sitúa en un nivel que escapa a lo cotidiano; al mismo tiempo, su forma es definitivamente excepcional en el ámbito de los tocados prehispánicos del área centro-sur andina, no habiéndose registrado hasta ahora fuera de la región estrictamente atacameña.

El testimonio de estas tabletas indicaría que tal tipo de tocado era el usado para identificar o connotar a las personas que participaban en el sacrificio, ya fuese como Víctimas o como Sacrificadores. En este punto es necesario recalcar que se trata de un gorro con orejas redondas, tal como son retratadas las orejas de los Antropomorfos Felinizados. La aparición de esta tableta en el extremo norte de Chile es absolutamente excepcional, y se inscribe en el amplio marco de los intercambios de larga distancia de objetos rituales de alto valor simbólico que se deben haber realizado entre curacas de etnias distantes, tal como ha venido siendo planteado por Llagostera (1996, 2006b) y Tarragó

Catarpe 5 que presenta a su vez cuatro ejemplares (de las tumbas 2372-2374, 2381 y 2390); aunque éstos no han podido ser ubicados actualmente, contamos con la descripción muy somera de las notas de Le Paige, quien no indica que hubiesen tenido orejas. 
(2006). El registro arqueológico azapeño y costero de Arica da cuenta del intercambio de varios otros bienes prestigiosos con el área de Tarapacá, Pica y río Loa, situación que no ha sido observada en relación con artefactos provenientes del salar de Atacama mismo (Horta 2010).

\section{El ícono doble-ancla}

Al iniciar la observación de los distintos elementos que suelen acompañar la vestimenta de las figuras antropomorfas propias del estilo que estamos definiendo, el ícono doble-ancla me pareció un signo aislado que no presentaba asociación con ningún otro elemento o personaje de la coreografía ritual que intentaba desentrañar. Sin embargo, más adelante fui percibiendo relaciones sutiles entre las imágenes talladas en diversos elementos del complejo alucinógeno, las que empezaron a bosquejar gradualmente una fina red de significados interconectados.

Torres -en el curso de sus investigaciones sobre elementos del complejo alucinógeno-, planteó que el "ornamento doble-ancla" habría formado parte de un conjunto de elementos iconográficos compartidos por las tabletas del noroeste de Argentina con las del Loa, y que dicho conjunto habría incluido también a seres humanos tocando la flauta de pan y el tema de la decapitación (Torres 1998: 53). Este mismo autor llamó la atención sobre el ornamento utilizado por el personaje de la tableta de Doncellas, Jujuy, Argentina, publicada por Krapovickas (aquí Figura 11a), relacionándolo con el del personaje de una tríada representada en la tableta 9160 de Caspana (véase Figura 5c). Tal como se puede apreciar en esta última figura, un personaje central que toca la antara es flanqueado por dos Antropomorfos Felinizados. El personaje de la flauta de pan ocupa el sitio que suele ocupar el Sacrificador cuando es flanqueado por dos antropomorfos encuclillados (posibles Víctimas según mi interpretación, tal como ya fue mencionado más arriba). Pero en este caso, no corresponde al Sacrificador porque no lleva la faja que es parte esencial de su atuendo. Por el contrario, toca la flauta de pan y en la frente luce el ícono doble-ancla. Se me planteó entonces la pregunta: ¿qué pudo haber significado este símbolo? y ipor qué luce en la frente de este personaje?

La siguiente analogía fue una espátula de madera proveniente del Pucara de Rinconada (Jujuy, Argentina; Torres 1987a: Plate 154), en cuyo mango fueron talladas dos fi- guras humanas de pie, con uno de sus brazos entrelazados por la espalda (Figura 11b). Lo notable de ellas es que presentan el ícono en la parte posterior de sus cabezas, a modo de insignia sobrepuesta al cabello. Por tanto, la escena de la espátula nos permite relacionar la dobleancla con dos personajes sin atributos de Sacrificador y que aparecen abrazadas. Este "gesto de abrazo" es significativo porque constituye el vínculo que nos permite reconocer en él a otras figuras humanas que entrelazan de igual modo sus cuerpos. Efectivamente, se trata del mismo gesto que realiza el Antropomorfo Complejo enmascarado cuando se ubica centralmente en algunas tríadas y presenta como ofrenda a las figuras humanas que lo flanquean (véase Figura $5 \mathrm{~d}$ ).

En síntesis, podemos decir que nos encontramos frente a la representación de un rito o ceremonia, en el cual se encuentran involucrados, por una parte, el gorro con dos orejas y el símbolo doble-ancla y, por otra, figuras humanas que lucen tales insignias y que simultáneamente pueden aparecer tocando una flauta de pan; también vimos que el Sacrificador puede igualmente tocar dicho instrumento (véase Figura 3b). Por otra parte, ha quedado en evidencia igualmente que el símbolo doble-ancla puede aparecer entre los ornamentos de Víctimas y Sacrificadores, indistintamente. Cada una de estas evidencias permite en conjunto cerrar el círculo detrás de los gestos y los objetos utilizados en el desarrollo de estas especiales escenas "coreografiadas".

Surgen paralelamente otras analogías entre los discos y placas de metal del Noroeste Argentino. Se trata de un disco de Pucarilla, provincia de Salta, considerado como de filiación cultural La Aguada (González 1977: 144; reproducida aquí en la Figuraıza), de una placa rectangular consignada como proveniente de Tiahuanaco y publicada por (González 1992: lam. 50B/1; reproducida en la Figura 12b), y de otra placa rectangular proveniente de La Rioja (González 1992: lam. 50B/3; reproducida aquí en la Figura 12c), así como de un disco - sin procedenciade excepcional belleza y excelente estado de conservación perteneciente a la colección del Museo de Artes Visuales de Santiago (Figura 13). Cada una de estas imágenes nos presenta complejas figuras antropomorfas junto con intrincados símbolos en representación frontal. El ícono doble-ancla es reconocible en la frente de las figuras, de la misma forma que lo vemos en la frente de algunas de las 


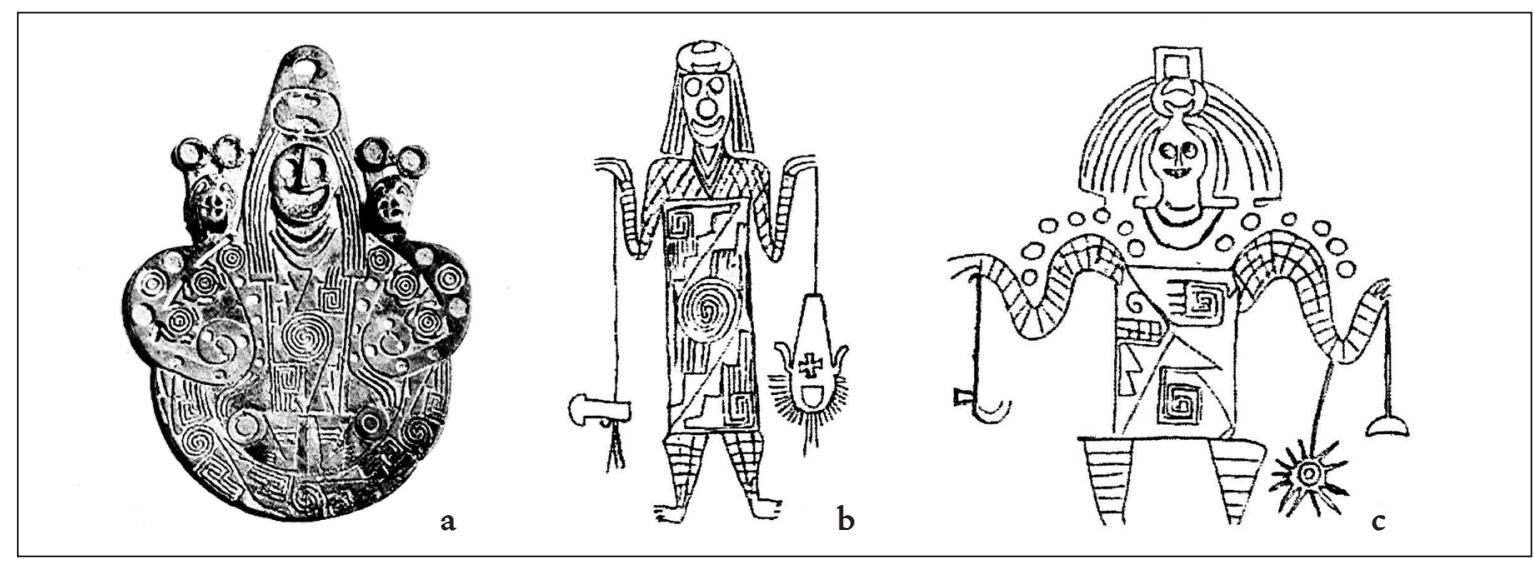

Figura 12. a) Disco de metal proveniente de Pucarilla, Salta (tomado de Pérez Gollán 1986: foto 3). b) Detalle de placa rectangular proveniente de Tiawanaku (tomado de González 1992: lám. 50B/1).c) Detalle de placa rectangular de La Rioja, Argentina (tomado de González 1992: lám. 50B/3).

imágenes talladas de la parafernalia alucinógena. Aunque se discute la identidad de dicho personaje frontal de discos y placas (González 1977; Pérez Gollán 1986), me parece plausible la idea de que corresponda a una deidad principal de la subárea Circumpuneña, cuyo culto podría haber sido compartido por sus habitantes; de ser así, esto arrojaría luces respecto al vínculo entre alguna deidad semejante y las víctimas humanas ofrendadas en su nombre; esta podría ser la razón por la cual la Víctima habría portado el símbolo del dios al cual era sacrificado. Esta idea se ve reforzada por el hecho de que los atributos del personaje frontal son precisamente hachas y -en uno de los casos presentados aquí-, cabezas cortadas con clara alusión al rito de la decapitación (véase Figura 12b).

\section{* La dimensión cronológica del estilo Circumpuneño}

Debido a la carencia de fechados absolutos para la gran mayoría de los contextos arqueológicos de los cuales provienen elementos del complejo alucinógeno con tallas del estilo que aquí analizamos, es preciso utilizar la información por asociación cerámica, textil o con otros tipos de artefactos arqueológicos para intentar su definición cronológica en términos relativos. Los datos contextuales de la Puna Argentina y la quebrada de Humahuaca indican que el hallazgo de tal tipo de objetos proviene -sin excepciones- de sitios o cementerios con material cultural del período Intermedio Tardío o de inicios del Tardío (Lehmann-Nitsche 1902; Ambrosetti 1908; Boman 1908; Von Rosen 1924; Casanova 1946, 1950; Salas 1945; Krapovickas 1958-59; véase el Apéndice 1 con la muestra utilizada).

A su vez, para el territorio atacameño (cuenca del Loa y salar de Atacama) todo indica que la ubicación temporal es semejante. Tal como ya se mencionó más arriba, Núñez estableció una importante diferencia espacial entre tabletas con rasgos Tiawanaku, con concentración en San Pedro de Atacama, y tabletas de estilo local con concentración en la cuenca del río Loa (Núñez 1963). Posteriormente, Torres (1998) dio un paso más al señalar que la concentración de tabletas estilo Tiawanaku en San Pedro correspondía al período Medio (300-1000 DC) y destacó la ausencia de este estilo en el Loa y en el noroeste de Argentina, indicando en dichas zonas la vigencia de otros estilos durante el Intermedio Tardío (1000-1400 DC). Al mismo tiempo, este autor planteó que las similitudes formales e iconográficas entre las tabletas loinas y las del noroeste argentino, sugerían interacción entre estos dos últimos territorios.

Llagostera señala dos momentos del período Medio, uno inicial entre el 500-900 DC, que evidenciaría "el mayor flujo de tabletas Tiawanaku" y uno posterior entre 900-1200 DC que marcaría la declinación de dicho flujo (Llagostera 2006a: 107); vale decir, las tabletas altiplá- 


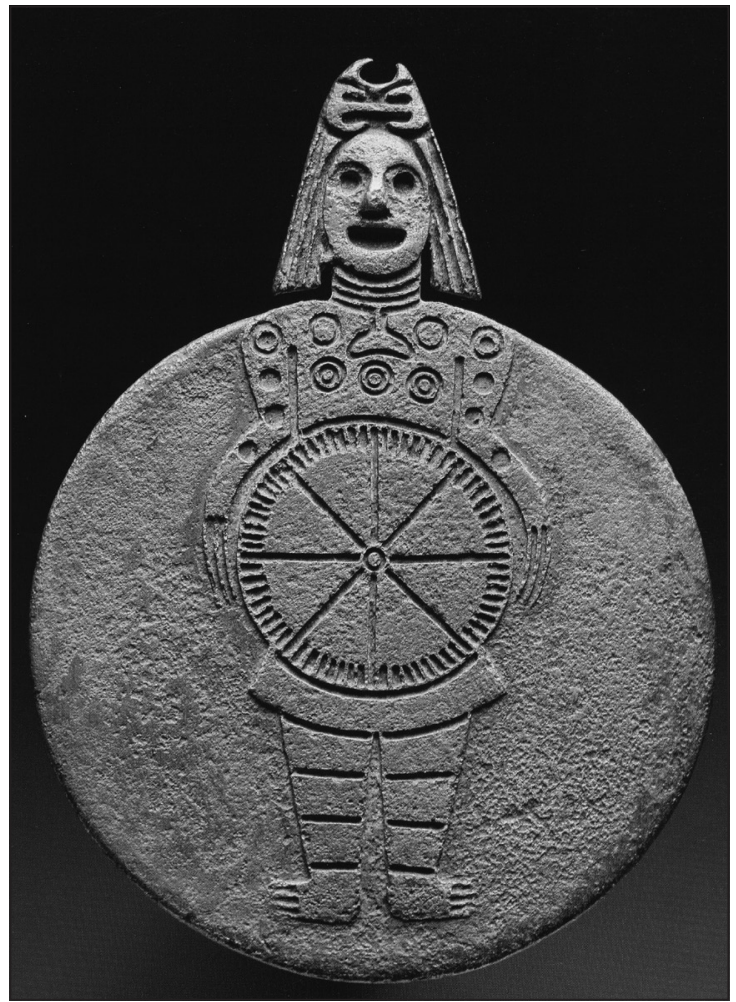

Figura 13. Disco de metal sin proveniencia. Colección del Museo de Artes Visuales, Santiago (tomado del Catálogo de exhibición Chile Indígena, 1991).

nicas se seguirían intercambiando, adaptando e incluso fabricando localmente ejemplares epigonales durante la primera mitad del Intermedio Tardío de San Pedro.

Por su parte, Tarragó en su estudio de la cerámica sampedrana analiza asociaciones contextuales que naturalmente incluyen tabletas y otros elementos del conjunto alucinógeno (Tarragó 1989). De ello se desprende que las tabletas de estilo Circumpuneño -que son efectivamente minoritarias respecto a las de estilo Tiawanaku y a otros estilos micro-locales que esperan por definición-, se concentran en cementerios de San Pedro con características o componentes culturales de los períodos Intermedio Tardío o Tardío como Solor 3, Tchecar Sur, Yaye 1, 3 y 4, Catarpe 2, Quitor 2 y 6. Recientemente he podido verificar dicha situación durante un estudio de colección realizado en el Museo R. P. Gustavo Le Paige de San Pedro de Atacama; junto con advertir una mínima presencia del estilo Circumpuneño en los contextos de los ayllus sampedra- nos, también he podido constatar la existencia de un subestilo local con temática propia, aunque enraizada en la ideología circumpuneña basada en la decapitación y el rito chamánico, que no trataré aquí ya que rebasaría el objetivo central de este artículo. En total, contamos con 26 piezas (entre tabletas y tubos) provenientes de cementerios de San Pedro y adscribibles al estilo Circumpuneño, lo cual en conjunto no superaría el 6\% del universo total de las tabletas sampedranas (ca. 465 ejemplares según los cálculos de Llagostera 2006a: 84).

Para la cuenca del río Loa contamos con la información aportada por Alliende (1981), Hermosilla (2001) y Ayala y colaboradores (1999). Todos estos investigadores coinciden en destacar la asociación de tabletas del estilo que estamos analizando y materiales culturales del Intermedio Tardío. Ayala y colaboradores plantean además la vinculación con el noroeste argentino, específicamente con la Puna de Jujuy, a través de la presencia de cerámica Yavi, calabazas pirograbadas de estilo La Paya y Santa María-Belén; esta situación les permite suponer "un sólido vínculo con las poblaciones de dicho territorio, por lo menos desde inicios del Intermedio Tardío" (Ayala et al. 1999: 46). De este mismo trabajo se desprende que no hay tabletas en tumbas con material cultural del período incaico, por lo tanto, esto constituiría un marcador temporal para la vigencia del estilo Circumpuneño, al menos en lo que dice relación con su presencia en el Loa.

Investigaciones futuras quizás permitan precisar más la situación de las tabletas del noroeste de Argentina, en donde su presencia es clara tanto en sitios del período Intermedio Tardío como del Tardío (Ambrosetti 1908; Casanova 1950; Pérez Gollán y Gordillo 1993). Montenegro menciona tres fechados realizados en materiales conexos con tabletas de Jujuy (Montenegro Ms); se trata de los sitios Arroyo La Matanza-Cusi Cusi, Los Amarillos y Juella, de donde se obtuvieron las siguientes fechas respectivamente: 1384 DC para un contexto que incluía una tableta con cabeza de felino; 1297-1436 DC para una tableta circular sin apéndices del recinto 16 de Los Amarillos, y 1300 DC para la habitación 21 de Juella, en donde también fue encontrada una tableta, cuya forma no es mencionada. Salas, por su parte, excavando en Ciénaga Grande una habitación excepcionalmente grande de pirca doble con dos adultos inhumados, encontró fragmentos de una tableta en directa conexión con un aríbalo 
pintado (Salas 1945), lo cual reafirma la presencia tardía del complejo alucinógeno en el noroeste de Argentina.

\section{* Discusión y CONClusiones}

Mi intención ha sido definir formal y temáticamente un conjunto de tallas en madera de características tridimensionales, figurativas y de carácter narrativo, cuya dispersión comprende la cuenca del río Loa y -en menor grado- San Pedro de Atacama en el norte de Chile, así como la Puna de Jujuy y la quebrada de Humahuaca, en el noroeste de Argentina. Esta área de dispersión del estilo refleja el actual estado de la investigación, por cuanto es esperable que en el futuro pudiesen descubrirse hallazgos en zonas que solo han empezado a explorarse en las últimas décadas, tales como Lipes y Chichas en el Altiplano Meridional (Angelo y Capriles 2004). En términos temáticos, he delineado un conjunto iconográfico que se compone del Antropomorfo Simple (Víctima) y del Antropomorfo Complejo (Sacrificador u Oficiante del sacrificio), además del Antropomorfo Felinizado o Custodio de Víctima, quien parece ser una variante del Sacrificador mismo, o su asistente en el rito. La forma de representación de uno y otro - tal como fue expuesto más arriba-, habría variado de acuerdo al rol que le cabía desempeñar durante los distintos momentos del rito. Las evidencias iconográficas indican que estos tres tipos de personajes están interconectados por sus respectivos roles en una "coreografía" ceremonial bien específica: la del sacrificio humano por medio del corte de la cabeza de una o más víctimas. Dicha iconografía posee rasgos particulares que la distinguen de la iconografía Tiawanaku, aunque al mismo tiempo es posible reconocer sus raíces en los lenguajes visuales de tierras altas compartidos por Pucara, Wari y Tiawanaku.

En síntesis, planteo que el análisis estilístico de las tabletas de estilo no-Tiawanaku de las regiones atacameña y noroeste de Argentina permite definir un estilo de carácter macro-regional con características propias, tanto formales como temáticas que propongo llamar tentativamente estilo Circumpuneño. Tomando en consideración los diferentes tipos de evidencias (estilísticas, iconográficas, arqueológicas y de dispersión geográfica), considero que este estilo es post-Tiawanaku y que su vigencia se habría mantenido durante el período de dominación incaica del área Circumpuneña.
En la iconografía de este estilo Sacrificadores y Víctimas se diferencian por la gestualidad relacionada con el rol de cada uno, posición corporal y objetos connotativos (vestimenta ad hoc, instrumento de la decapitación), sin embargo, el uso de la flauta de pan y del ícono doble-ancla es común para ambos. Sacrificadores y Víctimas se encuentran interconectados por los roles que desempeñan en la coreografía del ritual chamánico del sacrificio humano por medio de la decapitación de una o más Víctimas y la inhalación del alucinógeno depositado en las tabletas. Los Antropomorfos Felinizados custodiaban y asistían a las Víctimas en los preámbulos del rito, adoptando la posición corporal de éstas. Los Sacrificadores -vestidos de forma especial y ataviados con máscaras de felinos-, hacían la presentación de las Víctimas aún vivas ("Acto de presentación"). La Víctima tocaba la antara y luego se procedía a decapitarla. En ocasiones, el Sacrificador también tañía la flauta de pan mientras presentaba la cabeza cercenada.

El símbolo doble-ancla que se puede observar en la frente de los personajes de los discos provenientes del Noroeste Argentino, así como entre los atributos connotativos de algunos Sacrificadores, Víctimas y Antropomorfos Felinizados, induce a pensar que tal insignia podría haber representado a una deidad común circumpuneña y que en el marco de su culto se celebraba el sacrificio humano que nos "narran" las tabletas y tubos del complejo alucinógeno.

Considero que las evidencias analizadas en conjunto constituyen una base suficientemente sólida como para intentar establecer una secuencia tentativa de las acciones (reales o míticas), de las cuales estuvo alguna vez conformado el rito del corte de cabeza y sacrificio humano que parece haber sido práctica o creencia arraigada en el área circumpuneña. Las víctimas habrían sido sometidas a algún tipo de tratamiento especial en la víspera de la ceremonia, que habría incluido la inhalación de cebil, ingesta de chicha de maíz o chañar (arrope). Así podría deducirse de la postura corporal que adoptan y también de la pasividad que reflejan. Quizás las víctimas participaran en algún episodio donde la música apoyada por el sonido "rajado" de la antara era la gran protagonista (hemos visto que tanto la Víctima como el Oficiante del sacrificio tocan una flauta de pan en ciertas escenas). ${ }^{20}$ Las tríadas con Víctimas y Custodios grafica-

\footnotetext{
${ }^{20}$ Tomo la denominación de sonido "rajado" de Pérez de Arce (1995, 2004). A su vez, Gérard expresa en su estudio sobre la acústica
} 
rían dicho preámbulo de la ceremonia: los Antropomorfos Felinizados acompañan a los seres humanos que esperan ser sacrificados, sin portar ningún instrumento que delate el rito de decapitación que se realizará. La reconstrucción hipotética de la ceremonia -y la observación del tocado e insignia especial que lucen los Sacrificadores y las Víctimas mientras tañen la flauta de pan- permiten en conjunto comprender el significado de este tipo de escenas, que de otra forma podrían ser interpretadas como momentos de la vida cotidiana y no como pasajes de un complejo ritual. Posteriormente, las Víctimas habrían sido presentadas aún vivas por el oficiante ya investido de su rol de Sacrificador a través de vestimenta ad hoc, el cual en posición erguida rodeaba con sus brazos la espalda de las Víctimas (pasaje también observable en la composición visual de algunas tríadas). En la mayoría de los casos, el Sacrificador aparece en este momento de la secuencia como antropomorfo enmascarado de felino, utilizando sus conocidos referentes en forma de fauces con colmillos entrecruzados, morro destacado y orejas puntiagudas.

Aun cuando no se ha encontrado hasta el momento ninguna talla alucinógena que retrate el momento mismo de la decapitación, ésta puede deducirse a partir de las imágenes de Antropomorfos Complejos que portan los objetos del sacrificio. Igualmente, es posible inferir que el o los oficiantes de la ceremonia adoptaban la postura ritual del arrodillamiento para presentar la ofrenda a una deidad principal hasta hoy desconocida. En su oportunidad, Núñez destacó como prueba del nexo entre el rito del sacrificio humano y las tabletas para inhalar alucinógenos, el hallazgo realizado por Le Paige en Caspana; éste se trató de una tumba colectiva compuesta por una cabeza de infante dispuesta al interior de un cesto en el centro de la sepultura, y rodeada a la vez por los restos de veinticinco adultos (Le Paige 1958: 55, 1965: lam. 34; Núñez 1962: 47). Sugerentemente, en la ofrenda funeraria de este niño sacrificado se encontraron dos tabletas, dos espátulas y una "corona de paja trenzada" (probablemente un típico gorro atacameño, sensu Agüero 2000). Una de dichas tabletas (8973) era excepcionalmente cir-

del ayarachi boliviano prehispánico (o antara), que las intencionales discontinuidades internas de los tubos horadados en la piedra habrían provocado "sonidos multifónicos, disonantes, estridentes y pulsantes", situación que se supone habría aumentado la tensión interna del rito (Arnaud $2004 \mathrm{Ms}$ ). cular con dos apéndices en el borde en forma de cabezas de felinos enfrentadas, mientras que la otra (9160) correspondía precisamente a la tríada de nuestra Figura 5c, la cual constituye uno de los más bellos exponentes del estilo Circumpuneño.

Agradecimientos Expreso mis agradecimientos a Agustín Llagostera (ex director del Museo R. P. Gustavo Le Paige S. J. de San Pedro de Atacama), Gabriela Carmona (arqueóloga del Museo Francisco Fonck de Viña del Mar durante mi visita del año 2007), Pilar Alliende (Museo Chileno de Arte Precolombino, Santiago) y Francisco Téllez (ex director del Museo Regional de Iquique), por haberme dado la posibilidad en distintos momentos de analizar material custodiado por sus respectivos museos. Por lo mismo, agradezco la amable colaboración a Isabel Alvarado, directora subrogante del Museo Histórico Nacional, y Gregory Ortega, encargado de la colección arqueológica de dicha institución. A Myriam Tarragó por haberme brindado todo tipo de facilidades durante mis visitas realizadas al Museo Etnográfico Juan Bautista Ambrosetti de Buenos Aires, así como por la amabilidad de sus colaboradores Gabriela Ammirati, Alejandra Reynoso y Fernando Veneroso. A los colegas Nuriluz Hermosilla y Juan Chacama por haber compartido conmigo los resultados de sus respectivas investigaciones en el tema. En el marco de una pasantía realizada en distintos museos del NOA, no puedo dejar de destacar la amabilidad con que fui recibida en Tilcara por parte de Clara Rivolta, directora del Instituto Interdisciplinario y sus colaboradores Eli Aparicio y Armando Mendoza, así como la útil orientación entregada por Mónica Montenegro, todos del Museo Arqueológico Dr. Eduardo Casanova. En Jujuy, los agradecimientos son para Beatriz Cremonte y Gabriela Ortiz del Centro de Estudios Andinos (CREA), así como para Humberto Mamani de la Dirección de Cultura, Inés Pemberton, Coordinadora de Patrimonio y Museos de la Secretaría de Turismo y Cultura, Jorge Morales, Sebastián Peralta y Dina Piozzi del Museo Arqueológico Provincial, y en Salta, para Mirta Santoni, directora del Museo de Antropología. Con cada uno de ellos se estableció un diálogo fluido que enriqueció mi estadía en Argentina. Asimismo, menciono la generosidad de los colegas Pilar Alliende, Constantino Torres, José Pérez de Arce, Emily Stovel, Arturo Torres, Jorge Pavez, Carolina Agüero, Germán Manríquez y Valentina Figueroa, quienes -en diferentes momentos de la investigación- me obsequiaron mate- 
rial bibliográfico y/o fotografías que me fueron de gran utilidad. A Constantino Torres agradezco especialmente la detenida lectura que realizara a una versión previa de este artículo y a Christina Torres-Rouff la traducción al inglés del resumen de este artículo. En la última fase de este estudio pude hacer uso de la beca MECESUP 0703 ("Fortalecimiento e internacionalización de los estudios de postgrado con excelencia académica en ciencias antropológicas"), de la Universidad Católica del Norte, estudiando en el Musée du quai Branly, París, el material alucinógeno excavado en el área atacameña por las misiones de Créqui-Monfort y Sénéchal de la Grange. Dicha pasantía no habría sido posible sin el apoyo logístico de Valentina Figueroa y sin el soporte institucional de Paz Núñez-Regueiro, quien fue mi referente oficial durante la estadía. Mi profunda gratitud para ambas. Debo además señalar que esta investigación ha sido parcialmente financiada por el Proyecto de Investigación Asociativa de CONICYT Anillo ACT-96, por lo cual expreso mis agradecimientos a su director, Germán Manríquez.

* Apéndice 1. Muestra utilizada en el anÁlisis, procedencia y fuente bibliográfica de las piezas

\section{Tabletas con representación de víctimas}

\begin{tabular}{|c|c|c|}
\hline Procedencia & Descripción & Fuente bibliográfica o Museo \\
\hline La Paya & dos víctimas & tableta ovalada 2135; Ambrosetti 1908: Fig. 270 \\
\hline La Paya & dos cabezas humanas & tableta s/n; Torres $1987 \mathrm{a}$, Plate 165 \\
\hline La Paya & dos víctimas & tableta 1128; Ambrosetti 1908: Fig. 88 \\
\hline La Paya & una víctima & tubo 1126; Ambrosetti 1908: Fig. 87 \\
\hline La Paya & dos cabezas humanas & tableta 22.079; MEJBA; Ambrosetti 1908: Fig. 268 \\
\hline La Paya & una cabeza humana & tableta ovalada 1689; Ambrosetti 1908: Fig. 264 \\
\hline La Paya & una cabeza humana & tableta 22.090; MEJBA \\
\hline Pucara de Rinconada & dos víctimas abrazadas & espátula 242; Ambrosetti 1908: Fig. 16 \\
\hline Antigal de Ciénaga Grande & dos víctimas & tableta s/n; Torres 1987a, Plate $152 \mathrm{a}$ \\
\hline Calilegua & dos víctimas & tableta 13/3658; Torres 1987a: Plate 146 \\
\hline Doncellas & una víctima & tableta s/n; Krapovickas 1958: Figs. 9 y 10 \\
\hline Los Amarillos & dos víctimas & tableta 27.579; MEJBA \\
\hline La Huerta & dos víctimas & $\begin{array}{l}\text { tableta } 2994 \text { [25794]; Museo Arqueológico Dr. Eduardo Casanova, Tilcara. } \\
\text { Montenegro s/f: } 48\end{array}$ \\
\hline La Huerta & dos cabezas humanas & tableta 3016 [8625]; Museo Arqueológico Dr. Eduardo Casanova, Tilcara \\
\hline Angosto Chico & dos víctimas & tableta $\mathrm{s} / \mathrm{n} ; \mathrm{MEJBA}$ \\
\hline Angosto Chico & una víctima & tableta 3285 [37-831]; Museo Arqueológico Dr. Eduardo Casanova, Tilcara \\
\hline Purmamarca & dos víctimas & tableta 1410 [65673]; Museo Arqueológico Dr. Eduardo Casanova, Tilcara \\
\hline Chunchurí & dos víctimas & tableta 1999.1.177; Durán et al. 2000: Fig. 70 \\
\hline Chunchurí & dos víctimas & tableta 1999.1.174; Durán et al. 2000: Fig. 68 \\
\hline Chunchurí & dos víctimas & tableta 1999.1.173; Durán et al. 2000 : Fig. 67 \\
\hline Calama & dos cabezas humanas & tableta s/n; Torres $1987 \mathrm{a}$, Plate 66 \\
\hline Lasana & una víctima & tableta 15/9970; Torres 1987a, Plate 72 \\
\hline Lasana & víctima antarista & tableta 15/9969; Torres 1987a, Plate 67 \\
\hline Caspana & cuatro cabezas humanas & tableta de tumba 47, Los Abuelos; Torres 1987a: Plate 44 \\
\hline Caspana & dos víctimas & tableta 9006; MSPA \\
\hline Caspana & una víctima & tableta 23.033; Alliende 1981 \\
\hline Caspana & una víctima & tableta 23.054; Alliende 1981 \\
\hline Caspana & dos víctimas & tableta 23.127; Alliende 1981 \\
\hline Caspana & dos víctimas & tableta 23.072; Torres 1987a: Plate 38 \\
\hline Chiuchiu & dos víctimas abrazadas & tableta s/n; Uhle 1913: Fig. 4 \\
\hline Toconce & víctima antarista & tableta 14/3742; Torres 1999: Fig. 13 \\
\hline Coyo Oriente & una cabeza humana & tableta 8989 , tumba 5373; MSPA \\
\hline Costa II Región & dos víctimas & tableta s/n; Torres 1987a: Plate 27 \\
\hline Pisagua & una cabeza humana & tableta s/n; Uhle 1915: Fig. 5 \\
\hline Sin procedencia & una víctima & tubo 1919; MAVI \\
\hline Azapa-15 & una víctima & tubo 4946, tumba 9o; MRA \\
\hline
\end{tabular}


II. Tabletas con representación de sacrificadores (con y sin máscara) y antropomorfos felinizados

Procedencia

Chiuchiu

Chiuchiu

Chiuchiu

Chiuchiu

Chiuchiu

Chiuchiu

Chiuchiu

Chiuchiu

Chiuchiu

Chiuchiu

Caspana

Caspana

Caspana

Caspana

Caspana

Caspana

Caspana

Caspana

Caspana

Caspana

Caspana

Caspana

Calama

Calama

Calama

Chunchurí

Chunchurí

Chunchurí

Chunchurí

Chunchurí

Chunchurí

Chunchurí

Chunchurí

Chunchurí

Chunchurí

Chunchurí

Chunchurí

Chunchurí

Chunchurí
Descripción

dos antropomorfos felinizados

dos sin máscaras

un enmascarado

dos enmascarados

dos enmascarados

dos enmascarados

un antarista sin máscara

dos enmascarados

un enmascarado

dos sin máscaras

uno sin máscara

uno sin máscara

dos enmascarados

dos enmascarados

dos enmascarados

dos antropomorfos felinizados

dos enmascarados

dos enmascarados

dos enmascarados

dos antropomorfos felinizados

un enmascarado

dos enmascarados

dos enmascarados

dos enmascarados

uno sin máscara

un antarista sin máscara

uno sin máscara

dos sin máscaras

dos sin máscaras

dos antropomorfos felinizados

un enmascarado

un enmascarado

un enmascarado

un enmascarado

un enmascarado

un enmascarado

uno sin máscara

un enmascarado

un enmascarado
Fuente bibliográfica o Museo

tableta 41.0/8754; Torres 1987a: Plate 46

tableta 41.0.8745; Torres 1987a: Plate 55

tubo; Boman 1908: Fig. 174

Uhle 1913: Fig. 5

tableta 17/7552; Torres 1987a: Plate 135

tableta 8294; Oyarzún 1979: Fig. 8

tableta 41.0.3395; Torres 1987a: Plate 47b

tableta 41.0.8745; Torres 1999: Fig. 12

tubo; Mostny 1958: Fig. 8

tableta; Uhle 1913: Fig. 6

tubo 23.007; Alliende 1981

tableta 23.105; Alliende 1981

tableta 23.081; Alliende 1981

tableta 23.051; Alliende 1981

tableta 23.110; Alliende 1981

tableta 23.146; Alliende 198

tableta 23.165; Alliende 1981

tableta 23.167; Alliende 1981

tableta 23.065; Alliende 1981

tableta circular 8973; Torres 1987a: Plate 36

tableta s/n; Ayala et al. 1999: Fig. 4

tableta s/n; Ayala et al. 1999: Fig. 4

tableta s/n; Boman 1908: Fig. 172

tableta 4418; Oyarzún 1979: Fig. 7

tubo 8296; Oyarzún 1979: Fig. 13

tableta 1999.1.178; Durán et al. 2000: Fig. 71

tableta 1999.1.179; Durán et al. 2000: Fig. 55

tableta 1999.1.180; Durán et al. 2000: Fig. 56

tableta 1999.1.181; Durán et al. 2000: Fig. 57

tableta 1999.1.186; Durán et al. 2000: Fig. 50

tubo $\mathrm{S} / \mathrm{N}^{\circ}$; Torres 1987a: Plate 65

tubo 642; Oyarzún 1979: Fig. 15

tubo 1999.1.199; Durán et al. 2000: Fig. 60

tubo 1999.1.208; Durán et al. 2000: Fig. 61

tubo 1999.1.210; Durán et al. 2000: Fig. 62

tubo 1999.1.211; Durán et al. 2000: Fig. 63

tableta 1999.1.196; Durán et al. 2000: Fig. 58

tubo 1999.1.212; Durán et al. 2000: Fig. 64

tubo 1999.1.213; Durán et al. 2000: Fig. 65 


\begin{tabular}{|c|c|c|}
\hline Caleta Huelén-12 & uno sin máscara & tableta tumba 20; Torres 1987a: Plate 29 \\
\hline Caleta Huelén-12 & uno sin máscara & tableta tumba 12; Torres 1987a: Plate 30 \\
\hline La Paya & dos sin máscara & tableta 1373; Ambrosetti 1908: Fig. 61 \\
\hline La Paya & un enmascarado & tableta 1224; Ambrosetti 1908: Fig. 68 \\
\hline La Paya & un enmascarado & $\begin{array}{l}\text { tableta } 2137 \text { [596]; Museo Arqueológico Dr. Eduardo Casanova, Tilcara. Ambrosetti 1908: Fig. } \\
265\end{array}$ \\
\hline La Paya & uno sin máscara & tubo 1870; Ambrosetti 1908: Fig. 280 \\
\hline La Paya & un enmascarado & tubo 501; Ambrosetti 1908: Fig. 282 \\
\hline Santa Catalina & un enmascarado & tubo s/n; Lehmann-Nitsche 1902: Fig. 25 \\
\hline Santa Catalina & un enmascarado & tubo s/n; Lehmann-Nitsche 1902: Fig. 26 \\
\hline Rinconada & dos enmascarados & tableta 678; Ambrosetti 1908: Fig. 278 \\
\hline Campo Morado & dos antropomorfos felinizados & tableta 25.732; MEJBA \\
\hline Juella & dos antropomorfos felinizados & Tableta s/n; MEJBA \\
\hline Tilcara & dos enmascarados & tableta 22.082; MEJBA \\
\hline Pucara de Tilcara & un enmascarado & tubo 2229 [8698]; Museo Arqueológico Dr. Eduardo Casanova, Tilcara \\
\hline Valle Sta. María (Catamarca) & dos antropomorfos felinizados & tableta 34-181; MEJBA \\
\hline Yacoraite & un enmascarado & tableta 26.491; MEJBA \\
\hline Peñas Blancas & dos enmascarados & tableta oval 26.699; MEJBA \\
\hline Pucara de Lasana & dos sin máscara & tableta 2360, tumba 6; Torres 1987a: Plate 70 \\
\hline Chacance & un enmascarado & tubo $s / n$; Sin autor, 2002 \\
\hline Tchecar Sur & un enmascarado & tableta 20946, tumba 1171; Le Paige 1969: Fig. 4 \\
\hline Tchecar & uno sin máscara & espátula 821; Le Paige 1969: 92 \\
\hline Tchecar & uno sin máscara & tubo 1221; MSPA \\
\hline Catarpe 2 & un enmascarado & tableta 1777; MSPA \\
\hline S. P. de Atacama & un enmascarado & tubo s/n; Torres 1987a: Plate 139 \\
\hline Solcor-3 & uno sin máscara & tableta 1668; Llagostera et al. 1988: lám. 13 \\
\hline Quitor-5 & dos sin máscaras & tableta 9135, tumba 2094-2108; Torres 1987a: Plate 113 \\
\hline Quitor-5 & uno sin máscara & tableta 9151, tumba 2094-2108; Torres 1987a: Plate 114 \\
\hline Quitor-5 & uno sin máscara & tableta 9148, tumba 2077-2089; Torres 1987a: Plate 115 \\
\hline Pucara de Quitor & un enmascarado & tableta s/n; Torres 1987a: Plate 114 \\
\hline Solcor Nueva Población & dos enmascarados & tableta 9165, tumba 4779; MSPA \\
\hline Yaye-1 & dos sin máscaras & tableta 9005, tumba 5491-9293; MSPA \\
\hline Sequitor Alambrado & un enmascarado & espátula 1660; Le Paige 1969: Fig. 92 \\
\hline Toconce & uno sin máscara & tableta 14/3741; Torres 1987a: Plate 61 \\
\hline Paniri & dos sin máscaras & tableta 19.022; Col. Künsenmüller; MNHN, Santiago \\
\hline Río Loa & un antarista sin máscara & tableta s/n; Spahni 1967: Plate VII \\
\hline Río Loa & uno sin máscara & tableta 26386; Möntel 1926: Fig. 41 \\
\hline Caldera & dos sin máscaras & tableta S/No; Looser 1926: Fig. 2 \\
\hline Azapa-8 & uno sin máscara & tableta tumba Q1/4 o M27; Col. Julio Montané, MNHN, Santiago \\
\hline Sin procedencia & uno sin máscara & tableta s/n; Museo Regional de Atacama \\
\hline Sin Procedencia & un enmascarado & tableta s/n; MFONCK \\
\hline Sin procedencia & dos sin máscaras & tableta 1974; MCHAP \\
\hline Sin procedencia & uno sin máscara & tableta 1976; MCHAP \\
\hline Hornitos (?), Antofagasta & uno sin máscara & tableta 94.1.868; Museo Regional de Antofagasta \\
\hline Total: $8 \mathbf{2}$ & & $54.6 \%$ \\
\hline
\end{tabular}




\section{Tabletas con representación de tríadas}

(Antropomorfo Felinizado-Víctima-Antropomorfo Felinizado) (Víctima-Sacrificador-Víctima) (Víctima-Víctima Antarista-Víctima)

\begin{tabular}{|c|c|c|}
\hline Procedencia & Descripción & Fuente bibliográfica o Museo \\
\hline Caspana & $\mathrm{AF}-\mathrm{VA}-\mathrm{AF}$ & tableta 9160; Pérez de Arce 1995:39 \\
\hline Caspana & $\mathrm{AF}-\mathrm{V}-\mathrm{AF}$ & tableta 23.138 , tumba 1, desaparecida \\
\hline Caspana & $\mathrm{AF}-\mathrm{V}-\mathrm{AF}$ & tableta 22.998, tumba 14; Alliende 1981 \\
\hline Caspana & $\mathrm{AF}-\mathrm{VA}-\mathrm{AF}(?)$ & tableta oval 23.133, tumba 40; Berenguer 1987: Fig. 6a. \\
\hline Caspana & $\mathrm{V}-\mathrm{S}-\mathrm{V}$ & tableta 23.159; Alliende 1981 \\
\hline Caspana & $\mathrm{AF}-\mathrm{VA}-\mathrm{AF}(?)$ & tableta 23.153 , tumba 20 ; Torres 1987 a: Plate 42 \\
\hline Chiuchiu & $\mathrm{AF}-\mathrm{V}-\mathrm{AF}$ & tableta 41.0.8746; Torres 1987a: Plate 56 \\
\hline Chiuchiu & $\mathrm{V}-\mathrm{S}-\mathrm{V}$ & tableta 17/7960; MAI; Torres 1987a: Plate 53 \\
\hline Chiuchiu & $V-S-V$ & tableta; Uhle 1913: fig. 1 \\
\hline Chiuchiu & $V-S-V$ & tableta; Uhle 1913: fig. 2 \\
\hline Chunchurí & $\mathrm{V}-\mathrm{S}-\mathrm{V}$ & tableta 1999.1.176; Durán et al. 2000: Fig. 6 \\
\hline Chunchurí & $\mathrm{AF}-\mathrm{V}-\mathrm{AF}$ & tableta 4545; Oyarzún 1979: Fig. 5 \\
\hline Socaire-22a & $V-S-V$ & tableta 94.1.867; Museo Regional de Antofagasta \\
\hline Toconce & $\mathrm{V}-\mathrm{VA}-\mathrm{V}$ & tableta 14/3744; MAI; Torres 1987a: Plate 60 \\
\hline Toconce & $\mathrm{V}-\mathrm{VA}-\mathrm{V}$ & tableta 14/3742; MAI; Torres 1987a: Plate 59 \\
\hline Los Amarillos & $\mathrm{V}-\mathrm{V}-\mathrm{V}$ & tableta 26.640; MEJBA \\
\hline La Paya & $\mathrm{AF}-\mathrm{V}-\mathrm{AF}$ & tableta 1138; MEJBA; Ambrosetti 1908: Fig. 100 \\
\hline La Paya & VA - VA - VA & tableta 1223; MEJBA; Torres 1987a: Plate 167 \\
\hline La Paya & $\mathrm{V}-\mathrm{VA}-\mathrm{V}$ & tableta 1600; MEJBA; Ambrosetti 1908: Fig. 275 \\
\hline La Paya & $V-S-V$ & tableta 1591; MEJBA; Ambrosetti 1908: Fig. 276 \\
\hline Los Quilmes & $V-S-V$ & tableta; MEJBA; Ambrosetti 1908: Fig. 13 \\
\hline Los Amarillos & $\mathrm{AF}-\mathrm{V}-\mathrm{AF}$ & tableta 26.641; MEJBA; Torres 1987a: Plate 150 \\
\hline Pucara de Tilcara & $\mathrm{V}-\mathrm{V}-\mathrm{V}$ & tableta 2228; Museo Arqueológico Dr. Eduardo Casanova, Tilcara \\
\hline Tolombón & $\mathrm{AF}-\mathrm{V}-\mathrm{AF}$ & tableta 15/1489; Torres 1987a: Plate 172 \\
\hline Sin procedencia & $V-S-V$ & tableta 1989.389; Metropolitan Museum of Art, www.metmuseum.org \\
\hline Sin procedencia & $\mathrm{AF}-\mathrm{V}-\mathrm{AF}$ & tableta 3043-1, Museo de Amsterdam; Lapiner 1976: Plate 869 \\
\hline Azapa-15 (?) & $\mathrm{V}-\mathrm{V}-\mathrm{V}$ & tableta 367, MASMA, desaparecida (i?) \\
\hline Total: $\mathbf{2 7}$ & & $18 \%$ \\
\hline
\end{tabular}

\section{Tabletas con representación de dúos}

(Sacrificador-Víctima)

\begin{tabular}{lll}
\hline Procedencia & Descripción & Fuente bibliográfica o Museo \\
& $\mathrm{S}-\mathrm{V}$ & \\
Caspana & $\mathrm{S}-\mathrm{V}$ & tableta 23.168; Alliende 1981 \\
Caspana & $\mathrm{S}-\mathrm{V}$ & tableta 23.121; Alliende 1981 \\
Caspana & $\mathrm{S}-\mathrm{V}$ & tableta 23.068, tumba 32; Alliende 1981 \\
Sin procedencia & $\mathrm{S}-\mathrm{V}$ & tableta 1918; MAVI \\
Sin procedencia & & tableta 2565; MCHAP \\
\hline Total: 5 & & $3.3 \%$
\end{tabular}

Total: 5

$3 \cdot 3 \%$

Total de la muestra: 150 ejemplares (124 tabletas, 3 espátulas y 23 tubos para inhalar) 


\section{* Referencias citadas}

\section{Abreviaturas}

MA Museo de América, Madrid

MAI Museum of American Indian, Nueva York

MCHAP Museo Chileno de Arte Precolombino, Santiago

MASMA Museo Arqueológico San Miguel de Azapa, Universidad de Tarapacá, Arica

MRA Museo Regional de Arica (antecesor del MASMA)

MMME Museo Municipal de María Elena, Loa

MSPA Instituto de Investigaciones Arqueológicas y Museo R.P. Gustavo Le Paige, Universidad Católica del Norte, San Pedro de Atacama

MAVI Museo de Artes Visuales, Santiago (ex Museo Arqueológico de Santiago)

MNHN Museo Nacional de Historia Natural, Santiago

MHN Museo Histórico Nacional, Santiago

MEJBA Museo Etnográfico Juan Bautista Ambrosetti, Buenos Aires

MFONCK Museo Corporación Francisco Fonck, Viña del Mar

MRI Museo Regional de Iquique

AGÜERO, C., 2000. Fragmentos para armar un territorio. La textilería en Atacama durante los períodos Intermedio Tardío y Tardío. Estudios Atacameños 20: 7-28.

2007. Los textiles de Pulacayo y las relaciones entre Tiwanaku y San Pedro de Atacama. Boletín del Museo Chileno de Arte Precolombino 12 (1): 85-98.

ALLIENDE, P., 1981. La colección arqueológica "Emil de Bruyne" de Caspana. Tesis de licenciatura en Arqueología y Prehistoria. Facultad de Filosofía, Humanidades y Educación, Universidad de Chile, Santiago.

AMBROSETTI, J. B., 1908. Exploraciones arqueológicas en la ciudad prehistórica de La Paya (valle Calchaquí, Provincia de Salta). Campañas de 1906-07. Primera y segunda parte. Revista de la Universidad de Buenos Aires, Facultad de Filosofía y Letras, Publicaciones de la Sección Antropología 3, Buenos Aires.

ANGELO, D., y J. CAPRILES, 2004. La importancia de las plantas psicotrópicas para la economía de intercambio y relaciones de interacción en el altiplano sur andino. Chungara 36 (2): 1023-1035.

ARNAUD, G., 2004 Ms. Interpretación acústica del ayarachi lítico "Yura" de los museos Charcas. Trabajo presentado en las Jornadas Arqueológicas 2004 de los Museos Universitarios Charcas, Universidad San Francisco Xavier de Chuquisaca, Sucre.
AYALA, P., O. REYES y M. URIBE, 1999. El cementerio de Los Abuelos de Caspana: el espacio mortuorio local durante el dominio del Tawantinsuyu. Estudios Atacameños 18: 35-54.

BARÓN, A. M., 1984. Cráneos atacameños y su asociación con tabletas para alucinógenos. Simposio Culturas Atacameñas. XLIV Congreso Internacional de Americanistas: 147-155. Universidad del Norte, San Pedro de Atacama.

BERENGUER, J., 2007. Gorros para el desierto. Museo Chileno de Arte Precolombino, Santiago.

BOMAN, E., 1908. Antiquités de la région Andine de la Republique Argentine et du desert d'Atacama, vols. I y II, Paris.

CASANOVA, E., 1946. The cultures of the Puna and the Quebrada of Humahuaca. Bulletin 143, Handbook of South American Indians 2: 619-631. Goverment Printing Office, Washington.

1950. Restauración del Pucará. Facultad de Filosofía y Letras, Instituto de Antropología, Universidad de Buenos Aires, Buenos Aires.

DURÁN, E., 2001. La representación del músico en el Complejo Alucinógeno: tres casos en la Colección Max Uhle. Museos 25: 20-22.

DURÁN, E., M. F. KANGISER y N. ACEVEDO, 200o. Colección Max Uhle: expedición a Calama 1912. Publicación Ocasional 56: 5-49, Museo Nacional de Historia Natural, Santiago.

GONZÁLEZ, A. R., 1977. Arte precolombino de la Argentina. Introducción a su historia cultural. Filmediciones Valero, Buenos Aires.

1992. Las placas metálicas en los Andes del Sur. Contribución al estudio de las religiones precolombinas. Kommission für Allgemeine und Vergleichende Archäologie des Deutschen Archëologischen Institut, tomo 46, Bonn, Alemania.

GONZÁLEZ, R. A., y M. I. BALDINI, 1991. Función y significado de un ceramio de la cultura La Aguada: ensayo de interpretación. Boletín del Museo Chileno de Arte Precolombino 5: 23-52.

Hermosilla, N., 2001. The People of the Tumi, the Condor and the Jaguar. Psychoactive Plant Use in the Loa River Basin, Atacama Desert. Eleusis 5: 123-136.

HORTA, H., 2010. El señorío Arica y los reinos altiplánicos: complementariedad ecológica y multietnicidad durante los siglos pre-conquista en el norte de Chile (1000-1540 DC). Tesis de doctorado, Facultad Filosofía y Humanidades, Universidad de Chile, Santiago. 
IZIKOWITZ, K. G., 1933. L'origine probable de la technique du simili-velours péruvien. Journal de la Société des Americanistes, tomo XXV, fasc. 1, Paris.

KRAPOVICKAS, P., 1958-59. Arqueología de la Puna argentina. Anales de Arqueología y Etnología, tomos 14-15, Universidad Nacional de Cuyo, Facultad de Filosofía y Letras, Mendoza, Argentina.

LAPINER, A., 1976. Precolumbian Art of South America. Harry N. Abrams, Nueva York.

LATCHAM, R., 1926. El culto del tigre entre los antiguos pueblos andinos. Revista Chilena de Historia Natural 30: 125-136.

1938. Arqueología de la región atacameña. Prensas de la Universidad de Chile, Santiago.

LE PAIGE, G., 1958. Antiguas culturas atacameñas en la cordillera chilena (II Parte). Anales de la Universidad Católica de Valparaíso 4 y 5 , Valparaíso.

1969. Ricardo Latcham y el cementerio indígena de Tchecar (San Pedro de Atacama). Boletín del Museo Nacional de Historia Natural 30: 89-94.

LEHMANN-NITSCHE, R., 1902. Catálogo de las antigüedades de la provincia de Jujuy. Revista del Museo de La Plata, tomo XI, La Plata, Argentina.

LOOSER, G., 1926. Las tabletas para tomar rapé del Museo Nacional. Revista Chilena de Historia 30: 19-22.

LLAGOSTERA, A., 1995. Art in the snuff trays of the San Pedro de Atacama (Northern Chile). En Andean Art: Visual expression and its relations to Andean Beliefs and Values, P. Dransart (Ed.), pp. 51-77. Worldwide Archaeology Series, vol. 13, Inglaterra.

1996. San Pedro de Atacama: nodo de complementariedad reticular. En La Integración Surandina: Cinco siglos después, X Albó, M. I. Arratia, J. Hidalgo, L. Núñez, A. Llagostera, M. I. Remy y B. Revesz (Comps.), pp. 17-42. Estudios y Debates Regionales Andinos 91, Centro de Estudios Regionales Andinos Bartolomé de las Casas / Corporación Norte Grande / Taller de Estudios Andinos / Universidad Católica del Norte, Cusco-Antofagasta.

2001. Archaelogy of Hallucinogens in San Pedro de Atacama (North Chile). Eleusis 5: 101-121.

2006a. Contextualización e iconografía de las tabletas psicotrópicas tiwanaku de San Pedro de Atacama. Chungara 38 (1): 83-111.

2006b. San Pedro de Atacama y el sistema reticular de interacción puneña. En Esferas de interacción prehistóricas y fronteras na- cionales modernas: los Andes Sur Centrales, H. Lechtman (Ed.), pp. 303-328. Instituto de Estudios Peruanos, Lima.

LLAGOSTERA, A., y M. A. COSTA, 1984. Museo Arqueológico R. P. Gustavo Le Paige S. J. Ministerio de Educación, Santiago.

LLAGOSTERA, A., C. TORRES y M. A. COSTA, 1988. El complejo psicotrópico en Solcor-3 (San Pedro de Atacama). Estudios Atacameños 9: 61-98.

MONTENEGRO, M., Ms. S/F. Complejo alucinógeno e ideología: acerca del contexto simbólico de las tabletas para inhalación de sustancias psicoactivas de la Provincia de Jujuy, Argentina. Tesis de Licenciatura en Antropología, Facultad de Humanidades y Ciencias Sociales, Universidad Nacional de Jujuy, San Salvador de Jujuy.

MOSTNY, G., 1952. Una tumba de Chiu Chiu. Boletín del Museo Nacional de Historia Natural 26.

1968-69. Ideas mágico-religiosas de los "Atacamas". Boletín del Museo Nacional de Historia Natural 30: 129-143.

MUJICA, E., 1991. Pukara: una sociedad compleja temprana en la cuenca norte del Titicaca. En Los Incas y el antiguo Perú: 3000 años de historia, pp. 272-297. Sociedad Estatal Quinto CentenarioLunwerg Editores, España.

NÚÑEZ, L., 1961. Escultura antropomorfa prehispánica en el norte de Chile. Boletín de la Universidad de Chile 26:56-60.

1962. Tallas prehispánicas en madera. Contribución a la arqueología del norte de Chile. Tesis de licenciatura, Instituto Pedagógico, Facultad Filosofía y Educación, Universidad de Chile, Santiago.

1963. Problemas en torno a la tableta de rapé. Anales de la Universidad del Norte 2: 149-168.

1964. El sacrificador. Un elemento co-tradicional andino. Noticiero Mensual Museo Nacional de Historia Natural, año 8, núm. 96, Santiago.

1967. Informe arqueológico sobre una muestra de posible narcótico del sitio Patillos-1 (Provincia de Tarapacá, Norte de Chile). Arstryck 1967-68: 83-90.

OYARZÚN, A., 1979 (1931). Las tabletas y los tubos para preparar la paricá en Atacama. En Estudios Antropológicos y arqueológicos, pp. 112-120. Editorial Universitaria, Santiago de Chile.

PAREDES, R., 1984. El "degollador" (Nakaq) de Altarane, Puno. Gaceta Arqueológica Andina 11.

PÉREZ DE ARCE, J., 1982. La música en el arte precolombino. Museo Chileno de Arte Precolombino, Santiago. 
1995. Música en la piedra. Música prehispánica y sus ecos en Chile actual. Museo Chileno de Arte Precolombino, Santiago.

2004. Influencia musical de Tiwanaku en el norte de Chile: el caso del "siku" y de la "antara". En Tiwanaku. Aproximaciones a sus contextos históricos y sociales, M. A. Rivera, A. L. Kolata (Eds.), pp. 193-220. Ed. Universidad Bolivariana, Santiago.

PÉREZ GOLLÁN, J., 1986. Iconografía religiosa andina en el noroeste argentino. Boletín del Instituto Francés de Estudios Andinos, 15 (3-4): 61-72.

PÉREZ GOLLÁN, J., e I. GORDILLO, 1993. Alucinógenos y sociedades indígenas del noroeste argentino. Anales de Antropología 30: 299-350.

POCHETTINO M. L., A. R. CORTELLA y M. RUIZ, 1999. Hallucinogenic Snuff from Northwestern Argentina: Microscopical Identification of Anandenanthera colubrina var. cebil (Fabaceae) in Powdered Archaeological Material. Economic Botany 53 (2): 127-132.

SALAS, A., 1945. El antigal de Ciénaga Grande. Publicaciones del Museo Etnográfico de la Facultad de Filosofía y Letras, Serie A, vol. 5, Universidad de Buenos Aires, Buenos Aires.

SIN AUTOR, 2002. Chacance. Los primeros pampinos. Edición Museo María Elena.

SPAHNI, J. C., 1967. Recherches arqueologiques a l'embouchure du rio Loa. Journal de la Societe des Americanistes 61 (1):179-250.

TARRAGÓ, M., 1989. Contribución al conocimiento arqueológico de las poblaciones de los oasis de San Pedro de Atacama en relación con los otros pueblos puneños, en especial, el sector septentrional del valle Calchaquí. Tesis de doctorado, Universidad Nacional de Rosario, Facultad de Humanidades y Artes, Argentina.

2006. Espacios surandinos y la circulación de bienes en época de Tiwanaku. En Esferas de Interacción Prehistóricas y Fronteras Nacionales Modernas: los Andes Sur Centrales, H. Lechtman (Ed.), pp. 332-376. Instituto de Estudios Peruanos, Lima.

THOMAS W., C., y M. A. BENAVENTE, 1984. Reflexiones metodológicas acerca de las creencias en la cultura San Pedro a través del análisis de correspondencia de las tabletas de rapé. Universidad del Norte, San Pedro de Atacama.

TORRES, C., 1983. Tabletas para alucinógenos de San Pedro de Atacama: estilo e iconografía. En Tesoros de San Pedro de Atacama. Museo Chileno de Arte Precolombino, Santiago.
1984. Iconografía de las tabletas para inhalar sustancias psicoactivas de la zona de San Pedro de Atacama, norte de Chile. Estudios Atacameños 7: 178-196.

1986. Tabletas para alucinógenos en Sudamérica: tipología, distribución y rutas de difusión. Boletín del Museo Chileno de Arte Precolombino 1: 37-53.

1987a. The Iconography of South American snuff trays and Related Paraphernalia. Etnologiska Studier 37.

1987b. The iconography of the Prehispanic snuff trays from San Pedro de Atacama, Northern Chile. Andean Past 1: 191-254.

1998. Psychoactive Substances in the Archaeology of Northern Chile and NW Argentina. Chungara 30: 49-63.

2001a. Iconografía Tiwanaku en la parafernalia inhalatoria. Boletín PUCP 5: 247-454.

20o1b. Shamanic Inebriants in South America Archaeology: Recent Investigations. Eleusis 5:3-12.

TORRES, C., D. B. REPKE, K. CHAN, D. MACKENNA, A. LLAGOSTERA y R.E. SCHULTES, 1991. Snuff powders from Pre-Hispanic San Pedro de Atacama: Chemical and contextual analysis. Current Anthropology 32: 640-649.

TORRES, C. y W. CONKLIN, 1995. Exploring the San Pedro de Atacama/ Tihuanaku Relationship. En Andean Art: Visual Expression and his Relation to Andean Beliefs and Values, P. Dransant (Ed.), pp. 79-108. Worldwide Archaeology Series, vol. 13, Inglaterra.

UHLE, M., 1913. Tabletas de Chiu Chiu. Revista Chilena de Historia y Geografía 8: 454-457.

1915. Los tubos y tabletas para rapé de Chile. Revista Chilena de Historia y Geografia 16: 114-136.

VON ROSEN, E., 1924. Popular Account of Archaeological Research during the Swedish Chaco-Cordillera-Expedition 1901-1902. Estocolmo, Suecia.

WASSEN, H., 1965. The use of some specific kinds of South American Indian Snuff and related Paraphernalia. Etnoliska Studier 28.

1972. A medicine man's implements and plants in a Tiahuanaco tomb in highland Bolivia. Etnologiska Studier 32 